\title{
A View of the Canary Basin Thermocline Circulation in Winter
}

\author{
Volker Fiekas, ${ }^{1,2}$ JÜri Elken, ${ }^{3,4}$ Thomas J. Müller,${ }^{1}$ Ain Aitsam, ${ }^{3}$ and Walter ZenK ${ }^{1}$
}

\begin{abstract}
During January and February 1989 the recirculation of the subtropical gyre in the eastern North Atlantic was surveyed with a three-ship experiment. The analysis of hydrographic measurements and velocity data from a shipboard acoustic Doppler current profiler reveals the synoptic-scale circulation patterns and water mass distributions in the Canary Basin. The geostrophic transport stream function estimated with a horizontally varying reference level of no motion highlights the major currerts in three layers representing the vertical structure of the horizontal circulation. The classical circulation scheme is shown by the stream function in the upper $200 \mathrm{~m}$ : the Azores, Canary, and North Equatorial currents. Unlike the deep-penetrating Azores Current, the Canary Current and the North Equatorial Current are restricted to the upper $200 \mathrm{~m}$. Both carry North Atlantic Central Water along the kater mass boundary with South Atlantic Central Water. South Atlantic Central Water flows through the passage between the Cape Verde archipelago and Africa via narrow currents into the area north of $14.5^{\circ} \mathrm{N}$. At the southern edge of the subtropical gyre we identify an eastward flow of Antarctic Intermediate Water between 700 and $1200 \mathrm{~m}$.
\end{abstract}

\section{INTRODUCTION}

During the past decade, many efforts have been made to investigate the thermocline circulation in the eastern part of the North Atlantic subtropical gyre by analysis of historical data, investigations, and modeling. On the gyre scale, the analysis of climatological data [e.g., Stramma, 1984; Maillard, 1984, 1986; Olbers et al., 1985] confirms the recirculation patterns in the upper ocean and in the main thermocline of the eastern part of the gyre as depicted in the early density distribution at 200-m depth by Wüst [1936]. The gyre's northern dynamic boundary, the Azores Front (AF), with its associated current, the Azores Current (AC) [Käse and Siedler, 1982; Pollard and Pu, 1985; Gould, 1985; Käse et al., 1985; Sy, 1988; Klein and Siedler, 1989], carries some $10^{6} \mathrm{~m}^{3} \mathrm{~s}^{-1}$ into the eastern basin south of the Azores [Stramma, 1984]. This castward transport turns south in two branches, one west and one east of Madeira, and has an area of weak mean flow southwest of Madeira [Stramma and Siedler, 1988]. While the western branch, according to this analysis, serves directly as a root of the North Equatorial Current (NEC) system, part of the eastern branch feeds the Canary Current (CC) system, whose structure is strongly influenced by the seasonally varying trade winds and the resulting upwelling regime off northwest Africa [e.g., Krauss and Wübber, 1982; Hagen and Schemainda, 1989], before it also contributes to the North Equatorial Current. This then forms the southern dynamic boundary of the subtropical gyre and transports nearly pure North Atlantic Central Water (NACW) southwestward, west of the Cape Verde Islands. A water mass boundary separating North Atlantic Central Water from the South Atlantic Central Water (SACW) [Iagen, 1989] is found south and southeast of this

\footnotetext{
${ }^{1}$ Institut für Meereskunde an der Universität Kiel, Kiel, Germany.

${ }^{2}$ Now at Forschungsanstalt für Wasserschall- und Geophysik der Bundeswehr, Kiel, Germany.

${ }^{3}$ Institute of Thermophysics and Electrophysics, Academy of Sciences of Estonia, Tallinn.

${ }^{4}$ Now at Institute of Ecology and Marine Research, Academy of Sciences of Estonia, Tallinn.
}

Copyright 1992 by the American Geophysical Union.

Paper number 92JC01095.

0148-0227/92/92JC-01095\$05.00 dynamic boundary. Both boundaries together are described as the Cape Verde Frontal Zone (CVFZ) [Zenk et al., 1991].

As North Atlantic Central Water is carried by the gyre circulation, it interacts with other water masses. The most pronounced of these is the Mediterranean Water (MW) tongue, which spreads on nearly isopycnal surfaces into the eastern basin [Fedorov, 1976; Kuksa, 1983; Yemel'yanov and Fedorov, 1985; Käse and Zenk, 1987]. Within the Cape Verde Frontal Zone off the African coast, it meets Antarctic Intermediate Water (AAIW), which is much less saline and slightly less dense. Above the central waters lies the third characteristic water mass. It is marked by the subtropical salinity maximum $\left(S_{\max }\right)$ at shallow depths, around 100 to $150 \mathrm{dbar}$, and formed by cooling of extremely high salinity surface water and transported with the gyre circulation [Bauer and Siedler, 1988; Efimov and Boguslavski, 1989].

This general picture of the eastern subtropical gyre is of course subject to variations in both time and space. Stramma and Siedler [1988] derived seasonal pulsations of the gyre, with a shift of the Azores Current northward in winter and southward in summer, from the analysis of mean hydrographic data and directly measured velocity time series from mooring KIEL 276, west of Madeira (see Figure 1). Krawss and Wübber [1982] and Hagen and Schemainda [1989] predicted westward propagating baroclinic Rossby waves as a result of the annually changing trade winds at the eastern coast. Also on the annual scale, part of the North Atlantic Central Water is renewed by winter convection west of Madeira [Siedler et al., 1987], thus contributing to the ventilation of the thermocline [Luyten et al., 1983].

The eastern basin is filled with synoptic-scale eddies. Although they are much less energetic than their west Atlantic counter parts, they dominate the mean flow everywhere in the eastern basin [Dickson, 1983; Belkin and Kostianoy, 1988; Mäller and Siedler, 1992]. Their main energy sources may be found in the meandering and resulting instabilities of the Azores Current [Käse and Siedler, 1982; Siedler et al., 1985], the Canary Current [Bubnov and Navrotskaya, 1985] and the North Equatorial Current within the Cape Verde Frontal Zone [Onken and Klein, 1991] and possibly in the topographic intensification near the Azores and the Mid-Atlantic Ridge [Byshev et al., 1982].

With modern instrumentation and high spatial resolution, 


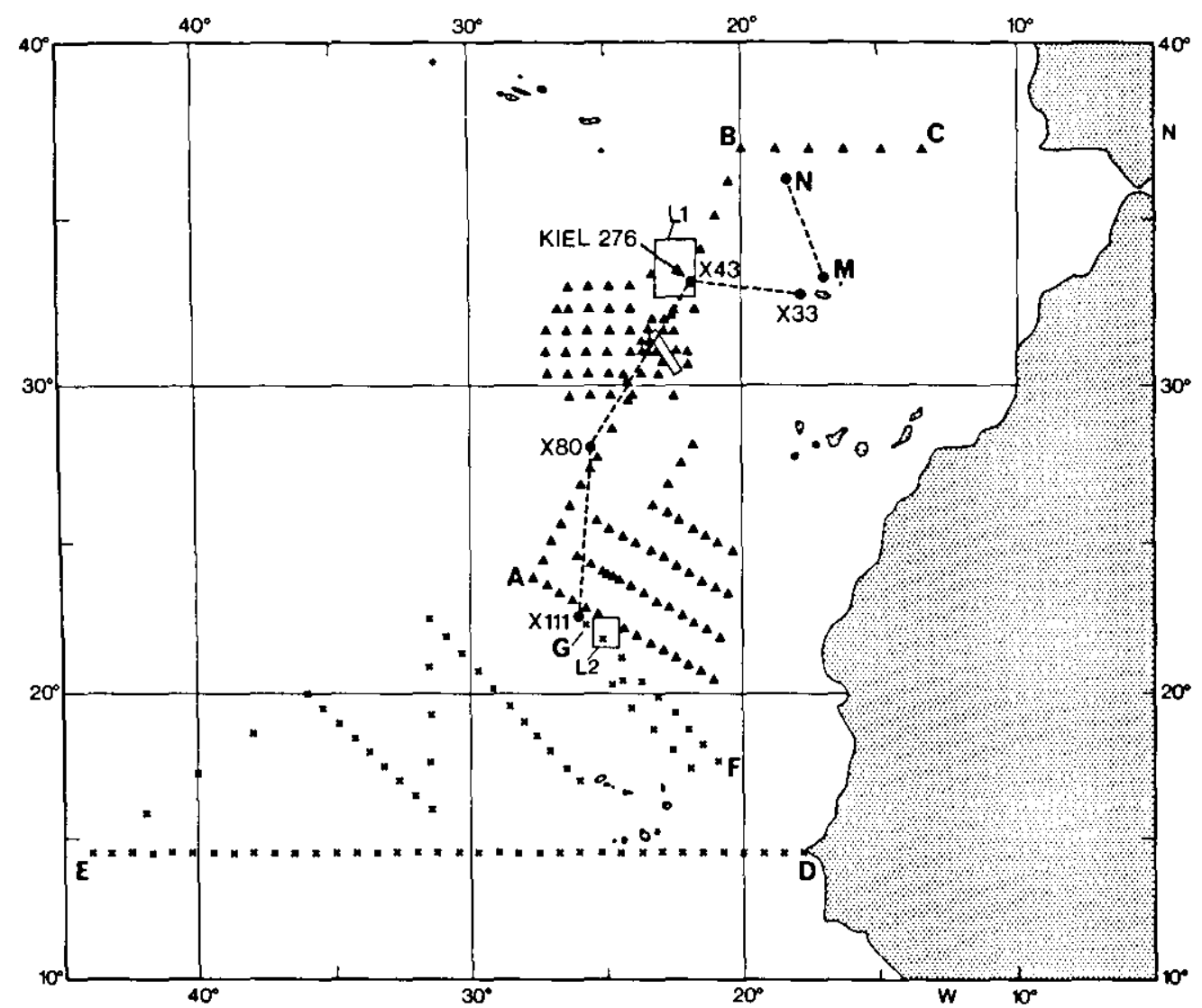

Fig. 1a. Locations of the CTD stations of FS Meteor cruise 9 (crosses), R/V Arnold Veimer cruise 27 (triangles and boxes L1, L2), and R/V Akademik Vernadsky (box L1). Sections discussed in the text are marked at end and turning points.

submesoscale saline lenses [McWilliams, 1985] with radii of $30-50 \mathrm{~km}$, thicknesses of $1000 \mathrm{~m}$, and lifetimes of up to 2 years have been observed within the Mediterrancan Water level as far as $2000 \mathrm{~km}$ from their assumed source [Armi and Zenk, 1984; Belkin et al., 1986; Schmitz et al., 1988; Armi et al., 1989]. Despite their small size, their dynamics can influence the circulation in the upper thermocline and the deep sea [see Siedler et al., 1985; Zenk and Mïller, 1988].

In this study we present the combined data sets from three

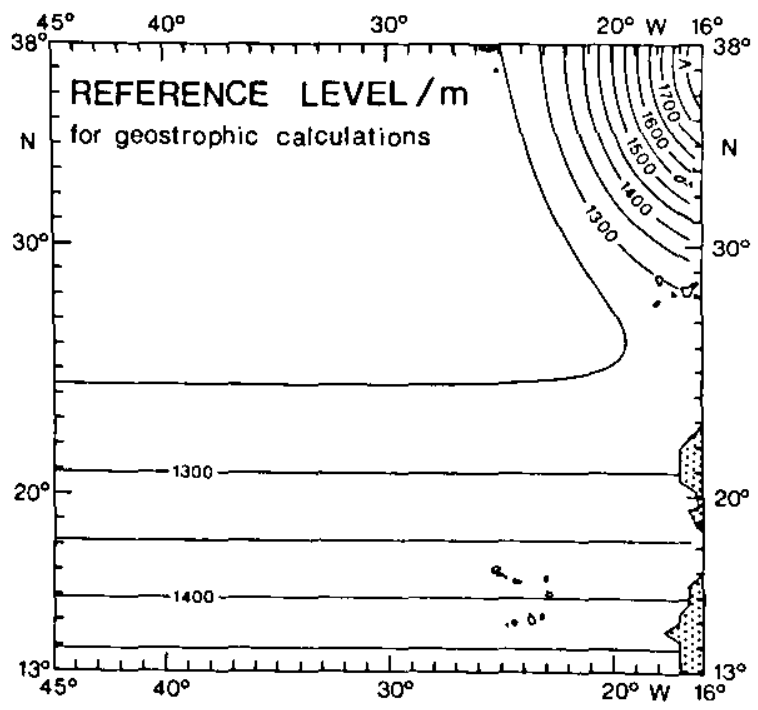

Fig. 1b. Reference level for geostrophic calculations. cruises, which originally were not coordinated but turned out to be quasi-synoptic, in the 2-month period January 8 to March 3, 1989 (Table 1 and Figure 1a). The Barlavento (Portuguese for "windward side") cruise aboard the German FS Meteor had three objectives: to study the Mediterranean outflow off Portugal, to service the long-term current meter mooring KIEL 276, and to investigate the circulation and mixing in the Cape Verde Frontal Zone north and west of the Cape Verde Islands (see crosses in Figure la for Meteor stations, Zenk et al. [1989] for a detailed cruise report, and Müller and Siedler [1992] for the analysis of current meter data). The Estonian R/V Arnold Veimer studied the large scale circulation and water mass distribution in the Canary basin, as well as the detailed structure and dynamics of meddies (Mediterranean eddies) in two mesoscale surveys in the AF and CVFZ frontal regions (boxes $\mathrm{LI}$ and $\mathrm{L} 2$ in Figure 1). In box L1, additional stations were obtained by the Ukrainian R/V Akademik Vernadsky.

We have combined the data sets from these cruises and will discuss some general features of the thermocline circulation in the Canary basin in late winter, 1989. Results from the meddy surveys in boxes LI and L2 will be discussed elsewhere.

\section{Methods}

\section{IIydrographic Measurements}

Neil Brown Mark III conductivity-temperature-depth (CTD) systems with rosette samplers were used. Standard procedures for in situ calibration and data processing were 
TABLE 1. Compilation of Data Sources Used for the Present Investigation From Meteor Cruises 9/1-3 (M), Arnold Veimer cruise 27 (AV), and Akademik Vernadsky (VE) With CTD Stations, XBT Drops, Sea Surface Temperature and Salinity, and Upper Ocean Current Profiles (ADCP)

\begin{tabular}{|c|c|c|c|}
\hline Source & Time, 1989 & Area* & Type of Data \\
\hline M9/1 & Jan. 8 & $\begin{array}{l}\mathrm{N} \\
\mathrm{N}-\mathrm{M}\end{array}$ & 5 CTD \\
\hline $\mathrm{M} 9 / 2$ & Jan. $12-25$ & west of Madeira to Cape Verde Islands & $\begin{array}{l}43 \text { CTD } 79 \text { XBT } \\
\text { SST, SSS, ADCP }\end{array}$ \\
\hline $\mathrm{M} 9 / 3$ & Jan. 26 to Feb. 17 & west of Cape Verde Islands, $14.5^{\circ} \mathrm{N}$ to Dakar & 70 CTD ADCP \\
\hline AV & Jan. 24 to Feb. 3 & grid west of Madeira & $50 \mathrm{CTD}, 75 \mathrm{~km}$ \\
\hline VE & Jan. 24 to Feb. 3 & grid west of Madeira & 40 CTD \\
\hline AV & Feb. $4-10$ & Ll (northern box) & 90 CTD, $2-20 \mathrm{~km}$ \\
\hline AV & Feb. 19-25 & section C-B-A & $23 \mathrm{CTD}, 100 \mathrm{~km}$ \\
\hline AV & Feb. 25 to March 13 & four sections normal to the African coast & $133 \mathrm{CTD}, 50 \mathrm{~km}$ \\
\hline AV & Feb. 27 to March 3 & L2 (southern box) & $85 \mathrm{CTD},<20 \mathrm{~km}$ \\
\hline
\end{tabular}

CTD, conductivity, temperature, and depth; XBT, expendable bathythermograph; SST, sea surface temperature; SSS, sea surface salinity; ADCP, acoustic Doppier current profiler.

*See Figure $1 a$.

applied to these data, resulting in final vertical profiles down to a common maximum pressure of $2000 \mathrm{dbar}$ with 10 -dbar resolution. The data sets compare well in their correlation of potential temperature and salinity within the Eastern North Atlantic Central Water.

Sections of hydrographic data were drawn using a horizontal smoothing spline interpolation scheme, usually resulting in $\mathrm{rms}$ differences between measured and interpolated values of one tenth of the contour interval. We note that varying the smoothing parameters had very little effect on the resulting contour plots.

The data set of our study is horizontally irregularly spaced with distances between neighboring stations reaching from $1 \mathrm{~km}$ to $300 \mathrm{~km}$. To avoid oversampling problems and the effects of nonsynoptic sampling when contouring large-scale maps, all data were averaged over half-degree latitudelongitude boxes. For mapping, we chose a kriging algorithm which has no smoothing during interpolation. Computational artifacts were suppressed by smoothing the interpolated data over 9 neighboring points with a $39-\mathrm{km}$ grid step.

To calculate the baroclinic part of geostrophic flows and to estimate its absolute value, one has to assume or derive some level of no (or known) motion. Stramma [1984] estimated a horizontally varying level of no motion from a historical data set that was averaged on $3^{\circ} \times 3^{\circ}$ squares. Using the method of Fiadeiro and Veronis [1982], he derived $1200 \mathrm{dbar}$ for a level of no motion near the Azores, $1300 \mathrm{dbar}$ near the mooring site KIEL $276\left(33^{\circ} \mathrm{N}, 22^{\circ} \mathrm{W}\right)$, and $1400 \mathrm{dbar}$ along $14^{\circ} \mathrm{N}$. The available long-term current meter measurements at KIEL 276 ( $8 \frac{1}{2}$ years) confirm the estimate near KIEL 276 [Müller and Siedler, 1992], and it will be shown later that our comparison of ADCP data with geostrophic profiles does not contradict Stramma's $1400-$ dbar estimate at $14^{\circ} \mathrm{N}$.

We therefore adopted a level of no motion as a function of latitude $\phi$ and longitude $\lambda$, in the form

$$
\begin{aligned}
P_{0}(\mathrm{dbar})= & 1200+0.69(\phi-32.9)^{2}+700 \\
& \cdot \exp \left\{-\left[(\phi-37)^{2}+(\lambda+14)^{2}\right] / 40\right\} .
\end{aligned}
$$

Here, the parabolic is a fit to Stramma's [1984] finding, and the Gaussian term is added to force the reference level below the Mediterranean Water core in the northeastern part of the area of investigation (see Figure $1 b$ ). To determine the corresponding geostrophic transport stream function with varying reference level and varying Coriolis parameter $f$ between two fixed pressure levels, we have used a first-order approximation (see the appendix for derivation and error discussion).

Potential vorticity will be used as a tracer of water mass circulation in the ocean [see McDowell et al., 1982]. Without forcing and dissipation, in regions of weak relative vorticity, and averaged over the eddy scale, potential vorticity is simply related to the vertical density gradient $\Delta \rho / \Delta z$ and local planetary vorticity $f$ by $q=(f / \rho)(\Delta \rho / \Delta z)$. Choosing two density levels $\rho_{2}$ and $\rho_{1}$, with $\Delta \rho=\rho_{2}-\rho_{1}$, and the corresponding vertical separation $\Delta z$ we may speak of $q$ as isopycnic potential vorticity (IPV) in the layer enclosed by the $\rho_{2}$ and $\rho_{1}$ surfaces.

\section{ADCP Measurements}

Continuous currents measurements were made from FS Meteor using a four-beam acoustic Doppler current profiler (ADCP) by RD Instruments. It operates at a frequency of $150 \mathrm{kHz}$ and is mounted on the ship's hull. The ADCP provided current profiles relative to the ship every 2-5 min in 8- to $16-\mathrm{m}$ bin lengths. These are rotated into geographical coordinates using the heading from the ship's gyrocompass, which is corrected with simultaneously recorded roll and pitch data, and averaged during a given sampling interval.

Recent studies by Joyce [1989] and Pollard and Read [1989] show that during ADCP in situ calibration, it is absolutely essential to estimate the transducer misalignment angle $\alpha$ and the scaling factor $A$. During the survey, $\alpha$ and $A$ were determined by several series of right angle turns (zigzag runs), and all acoustically measured current profiles were corrected with this in situ calibration.

The resulting profiles were integrated over the time interval between two successive fixes of the ship's position available from the satellite navigation systems, either Global Positioning System (GPS) or TRANSIT, the time interval being typically 1 hour. A worst case assumption then gives random errors of absolute currents estimates along the ship track of 0.05 to $0.1 \mathrm{~m} \mathrm{~s}^{-1}$ depending on the navigation system. Compared with this error, the inaccuracy due to the statistical error in Doppler frequency measurements is rather 
small and for an 1-hour averaging interval is less than 0.005 $\mathrm{m} \mathrm{s}^{-1}$.

\section{Water mass Distribution, Gfostrophy, and} associated Current and Frontal Structures

To identify water masses and associated depth ranges, as well as major frontal regions, we start with a discussion of selected vertical sections. A description of the horizontal distribution of properties and flow in identified typical common depth ranges of water masses follows.

\section{Vertical Sections}

We choose three typical CTD (0-2000 dbar) and one expendable bathythermograph (XBT) $(0-750 \mathrm{~m})$ transects, augmented with additional near-surface temperature and salinity data. The CTD section ABC (Figure 2; see Figure $1 a$ for location) by A. Veimer began on February 19, 1989. Four weeks earlier, Meteor obtained near-surface data (MN; Figure 3) and a XBT transect (X111 to X33; Figure 4) complementary to $\mathrm{ABC}$. The two southern sections, GF (Figure 5) across the Cape Verde Frontal Zone and ED (Figure 6) along $14.5^{\circ} \mathrm{N}$, were taken by Meteor between January 18 and February 16, 1989. On horizontal scales of more then $200 \mathrm{~km}$ and vertical scales more than $30 \mathrm{dbar}$, Figure 7 displays an overview of the water masses present.

Section ABC follows the meridional axis of the Canary basin north and turns east at the latitude of the Azores (position B). The zonal segment (BC) follows the Azores Ridge [Dietrich and Ulrich, 1968], which forms the topographic border between the Iberian and the Canary basins connecting Cape St. Vicente with the Azores archipelago. The eastern part of section $A B C$ cuts through the northern slope of the Josephine Bank at label JB.

The upper parts of Figures $2 a$ and $2 b$ display typical temperature and salinity sections in winter, with a convectively mixed layer of approximately $150 \mathrm{~m}$ depth and characteristic isotherm and isohaline outcrops. Within the mixed layer, near-surface temperature $\left(15^{\circ} \leq T_{0} \leq 21^{\circ} \mathrm{C}\right)$ and salinity $\left(36.1<S_{0}<37.2\right)$ increase toward the south. Beneath it the main thermocline with Western North Atlantic Central Water (WNACW in Figure $7 a$ [Emery and Meincke, 1986] and Eastern North Atlantic Central Water (ENACW) reaches down to 600 to $700 \mathrm{dbar}$. In this depth range, we recognize a remarkable difference between $A B$ and BC. The Azores Front [Käse and Siedler, 1982], just south of the turning point $B$ near $35^{\circ} \mathrm{N}, 21^{\circ} \mathrm{W}$, rules the picture. It is represented by an increase of isoline depth $\left(15^{\circ} \mathrm{C}\right.$ or $\left.36 \mathrm{PSU}\right)$ of $150 \mathrm{dbar}$ over less than $140 \mathrm{~km}$ distance.

The lower thermocline ( $>600 \mathrm{dbar}$ ) of section $\mathrm{ABC}$ is characterized by two intermediate water masses (see also Figure 7), low-salinity $(S<35.2)$ Antarctic Intermediate Water, at roughly $1000 \mathrm{dbar}$ in the south and the warm, high-salinity Mediterranean Water $(S>36.2)$, and a temperature inversion in the main core [Zenk and Armi, 1990] at about $1200 \mathrm{dbar}$ in the north and the east. Both areas are separated by a region of isolated patches with local salinity maxima. From previous investigations we know this area to be often populated with anticyclonic vortices or meddies [Armi and Zenk, 1984; Belkin et al., 1986].

Several salinity fronts are evident in section $A B C$. The vertical orientation of selected isohalines below $600 \mathrm{~m}$ indicates two strong internal fronts which both have expression
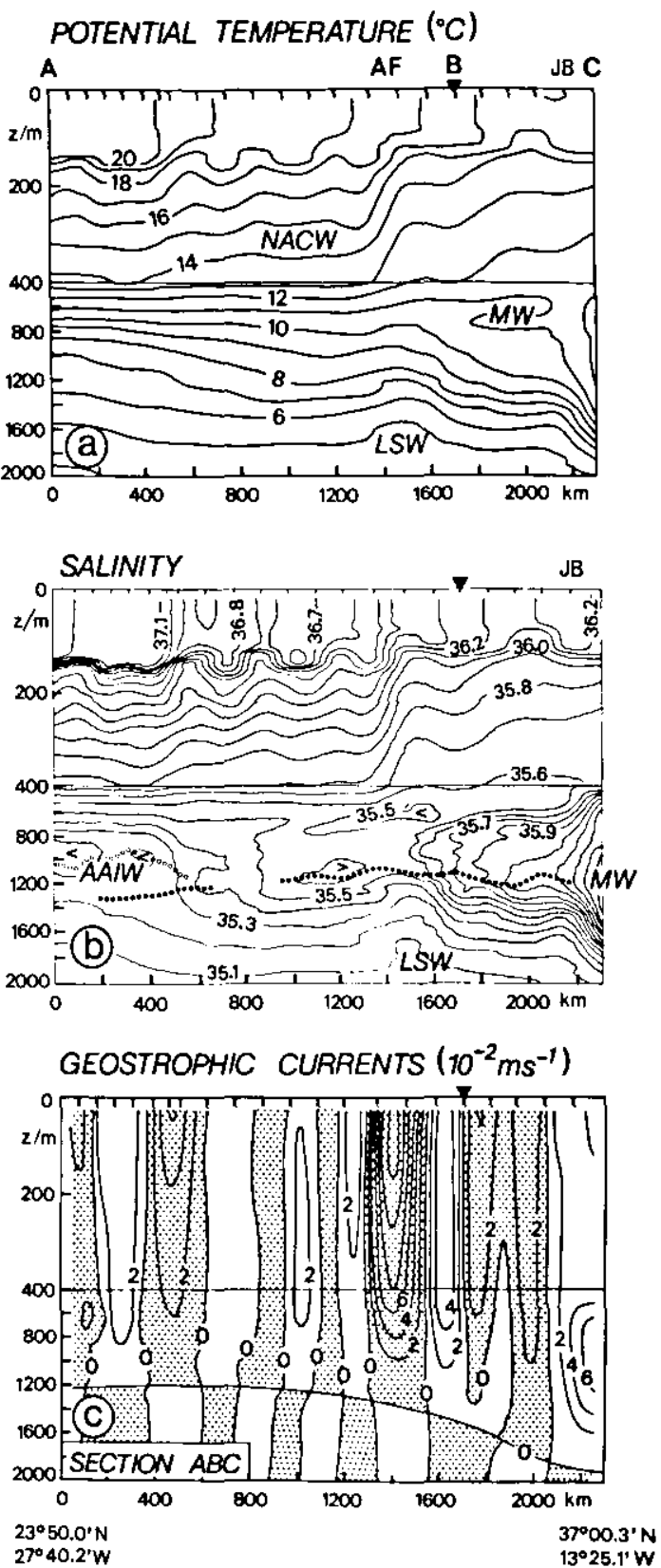

Fig. 2. Hydrographic transect along section ABC. Also included are characteristic water masses. North Atlantic Central Water, Mediterranean Water, and Labrador Sea Water. JB labels the position of the Josephine Bank; AF marks the Azores Front. (a) Potential temperature. (b) Salinity. Solid dots point out the salinity maximum and open circles show the salinity minimum. (c) Geostrophic currents. Shaded regions indicate currents coming out of the picture.

in the upper thermocline and halocline. The first front ( $S=$ $35.3)$ is related to a high-pressure cell position, to be discussed later, and the second internal front $(S=35.6)$ lies just north of the Azores Front. Another frontlike structure is observed in section BC just east of Josephine Bank, where the upper and the main Mediterranean Water cores approach each other and overlap and where the extraordinary thickness (pressure difference, $1500 \mathrm{dbar}$ ) of the Mediterranean Water tongue is reduced to a more typical value of $600 \mathrm{dbar}$ at a pressure level of $1200 \mathrm{dbar}$. The cold, low-salinity' intrusion at 1700-1800 dbar resembles a similar observation 

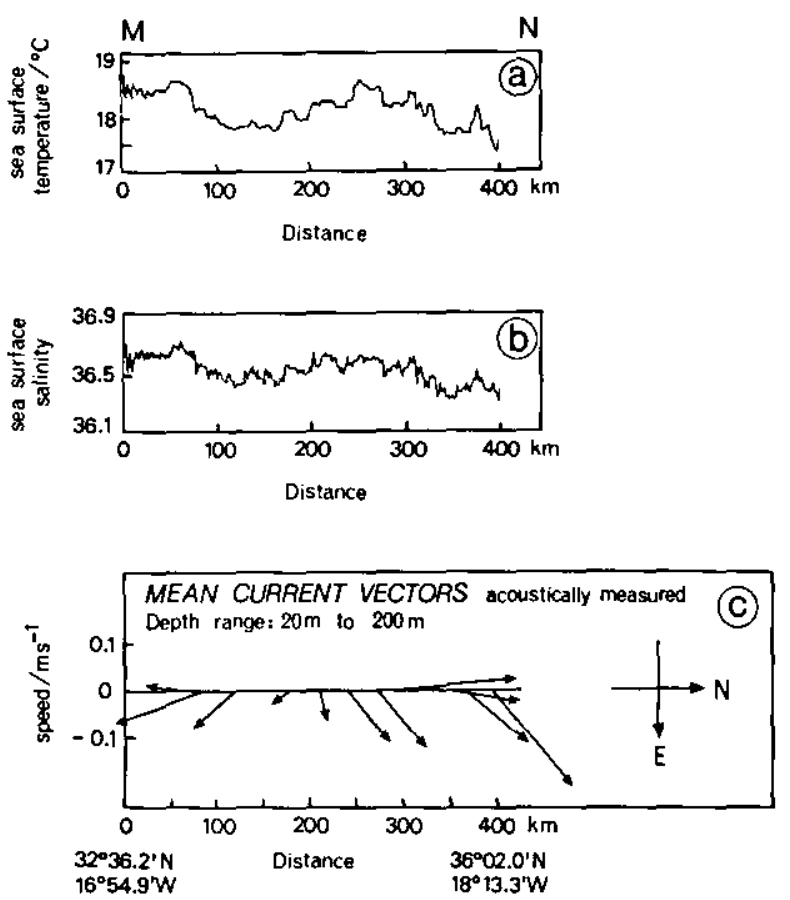

Fig. 3. Hydrographic transect along section MN. (a) Sea surface temperature. (b) Sea surface salinity. (c) Current vectors measured by a shipborne acoustic Doppler current profiler vertically averaged between $20 \mathrm{~m}$ and $200 \mathrm{~m}$.

in the Canary basin, interpreted by Käse et al. [1986] as Labrador Sea Water (LSW).

The distribution of geostrophic currents in Figure $2 c$ is referenced to the variable level of no motion given by equation (1). The strongest geostrophic signal is given by the Azores Current ( $>12 \mathrm{~cm} \mathrm{~s}^{-1}$, kilometer 1400), with adjoining weaker countercurrents. The Azores Current transports about $12 \times 10^{6} \mathrm{~m}^{3} \mathrm{~s}^{-1}$ to the southeast. The two countercurrents just north and south of it reduce the total transport to about $7 \times 10^{6} \mathrm{~m}^{3} \mathrm{~s}^{-1}$.

To demonstrate a more detailed surface thermohaline and subsurface velocity structure of the Azores Current north and west of Madeira, we combine all available underway measurements collected from January 9 to 18, 1989, in Figures 3 and 4. Along section MN north of Madeira, the surface temperature and salinity document clearly the position of the Azores Front on January 9, 1989, near kilometer 100 of the section (Figures $3 a$ and $3 b$ ). This position of the front is also confirmed by the ADCP observations (Figure $3 c$ ) with dominant southeastward flow between Madeira and $34^{\circ} 20^{\prime} \mathrm{N}$ (kilometer 200 in Figure $3 c$ ) and northeastward flow in the northern part of this section.

West and south of Madeira a long XBT section connects positions X33, X43, X80, and X111 (Figure $1 a$ ). The simultaneously recorded thermosalinograph data are displayed together with the XBT measurements in Figures $4 a$ to $4 c$. From south to north, both surface temperature and salinity decrease, from $22^{\circ} \mathrm{C}$ to $18.5^{\circ} \mathrm{C}$ and from 37.3 to 36.6 , respectively (Figures $4 a$ and $4 b$ ). These continuous surface records show that the decrease is stepwise with typical scales of $O(200 \mathrm{~km})$, relatively homogeneous regimes alternating with strong fronts, and that they are persistent with depth, as is shown in Figure $4 c$ by the highly resolved subsurface thermal structure. The gyre-scale circulation shows by the large-scale trough formed by the isotherms. The mixed layer depth marked by the large vertical temperature gradient in Figure $4 c$ lies at $100 \mathrm{~m}$. Below this depth the frontal zones are even more obvious than close to the surface. Temperature increases sharply between kilometers 900 and 1100 and between kilometers 1150 and 1300 . These two zones are marked as $\mathrm{AC}_{1}$ and $\mathrm{AC}_{2}$ in Figure $4 c$, and they flank a narrow $50 \mathrm{~km}$ wide region of ascending isotherms. The temperature increase of more than $1 \mathrm{~K}$ in zones $A C_{1}$ and $\mathrm{AC}_{2}$ is correlated in both cases with a band of strong currents measured acoustically (Figure $4 d$ ). We interpret these as the two branches of the Azores Current which were described recently from a historical data set by Stramma and Siedler [1988] and Klein and Siedler [1989]. The good agreement between our quasi-synoptic observations and their historical data, which are averaged over long periods of time and large areas, is unexpected but nevertheless an independent hint of the branching of the Azores Current in the Canary basin west of Madeira.

The CTD section GF (Figure 5) extends from the inner subtropical gyre towards its southeastern edge, cutting the Canary Current and the Cape Verde Frontal Zone. The upper water column shows a clear tilt of isotherms and isohalines separating North and South Atlantic Central Water (see also Figure $7 a$ ). Following a suggestion by Barton [1987], one may define the location of the CVFZ as where the 36.0 isohaline crosses the 150 -dbar pressure level. Between 50 and 100 dbar and on both sides of the front, lies a pronounced salinity maximum layer interpreted by Bauer and Siedler [1988] as Subtropical Salinity Maximum Water $\left(S_{\max }\right.$ in Figure $7 a$ ). It is formed by the combined excess of evaporation and winter cooling.

From the Cape Verde Frontal Zone toward the northwest (to the left in Figure 5), we find two water masses at middepth. The Antarctic Intermediate Water at the 1000 dbar level ( $S<35.00$ ) overrides Mediterranean Water $(S>$ 35.10) at about $1350 \mathrm{dbar}$, contrary to the situation farther north where both meet at the same level in a stronger frontal zone (compare Figure $2 b$ ).

The geostrophic velocity field along GF (Figure $5 c$ ) shows intense signals near the surface, whereas below $200 \mathrm{~m}$, currents are generally weak $\left(\sim 0.02-0.03 \mathrm{~m} \mathrm{~s}^{-1}\right)$. Only at position $\mathrm{F}$ do we find a deep westward flowing jet with $0.1 \mathrm{~m}$ $\mathrm{s}^{-1}$ surface velocity and $0.05 \mathrm{~m} \mathrm{~s}^{-1}$ at $600 \mathrm{~m}$ depth.

The mean distance between two successive ADCP absolute current profiles is roughly $30 \mathrm{~km}$ along all sections in the following discussion. Therefore these currents are interpolated on a grid with $30-\mathrm{km}$ horizontal spacing along the transects. To compare these directly measured velocities with the geostrophic current section, it is convenient to present the ADCP component perpendicular to the section (Figure $5 d$ ). It should be noted that the ADCP measurements cover mainly the mixed layer, where strong ageostrophic effects due to meteorological forcing mask the purely geostrophic signal. Nevertheless, there are remarkable similarities between the ADCP and the geostrophic sections. The strong geostrophic jet at position $F$, associated with the thermohaline signal of the front, is confirmed by the acoustic measurements, as are the other features toward position $\mathrm{G}$ (kilometer 0 ), shown in Figures $5 c$ and $5 d$. Note that the ADCP measures clearly higher speeds than the geostrophic calculation yields, except near F. As will be shown later in the horizontal maps for the upper $200 \mathrm{~m}$ 

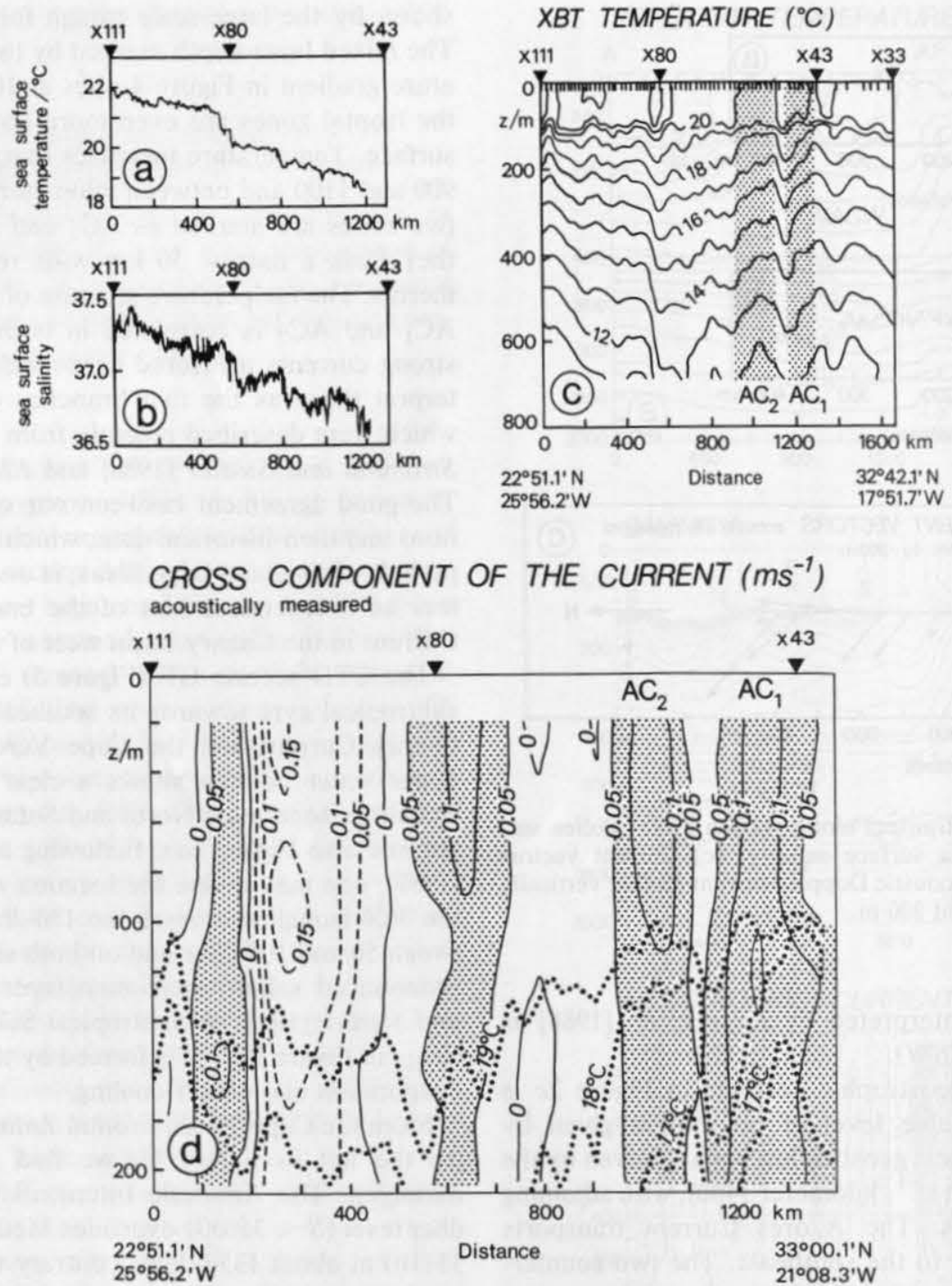

Fig. 4. Hydrographic section between X111 and X33. (a) Sea surface temperature. (b) Sea surface salinity. (c) Subsurface temperature obtained by XBT profiles. (d) Acoustically measured velocity component perpendicular to the section. Solid lines indicate currents coming out of the picture. Selected isotherms are included for reader's guidance. Note the change in scale in Figure $4 d$. Shaded regions in Figures $4 c$ and $4 d$ mark the frontal zones $\mathrm{AC}_{1}$ and $\mathrm{AC}_{2}$.

(Figure 8), section GF crosses a strong westward flow north of the Cape Verde Islands, carrying South Atlantic Central Water (Figure $5 b$ ) to the North Equatorial Current.

The hydrography between the Mid-Atlantic Ridge at $44^{\circ} \mathrm{W}$ and the African shelf is illustrated in section ED (Figure 6), at roughly $85-\mathrm{km}$ horizontal spacing. In addition to CTD stations and acoustically measured currents we also make use of silicate measurements and a well-defined potential temperature silicate relation (see Figure $7 b$ ) with relatively high silicate values in waters of South Atlantic compared with North Atlantic origin. The mixed layer, with temperature higher than $24^{\circ} \mathrm{C}$ and salinity around 36 , shallows toward the east and becomes cooler and fresher. This indicates advection of surface water, which probably originated in the South Atlantic. Below the mixed layer at about 100 -m depth, a tongue of high-salinity water $\left(S_{\max }\right)$ reaches from the Mid-Atlantic Ridge $(S>37)$ close to the African coast $(S>36)$.

In the upper waters below the shallow salinity maximum, the doming of isotherms (e.g., $12^{\circ} \mathrm{C}$ ) and isohalines (35.5) reaches a maximum near the eastern edge of $\mathrm{ED}$, separating the western roots of the North Equatorial Current from the eastern "shadow zone," which reaches across to the Cape Verde archipelago. North Atlantic Central Water dominates along the whole section. Mesoscale thermohaline structures coupled with anomalies in the silicate distribution (Figure $6 e)$ are observed only from kilometer 2200 on between the Cape Verde archipelago and the African shelf, including intrusions of South Atlantic Central Water into regimes otherwise dominated by North Atlantic Central Water. As will be seen below, these intrusions are related to strong northward current features.

In the lower part of Figures $6 b$ and $6 e$ we again identify the low-salinity, silicate-rich Antarctic Intermediate Water with its core at $850 \mathrm{dbar}$. Its salinity increases and its silicate decreases to the east, which can be caused by mixing with underlying saltier, lower-silicate waters [Wüst, 1936]. The deep salinity maximum and silicate minimum at 1650 dbar indicates Upper North Atlantic Deep Water (UNADW; see also Figure $7 a$ ), with origin further north. Salinity values 

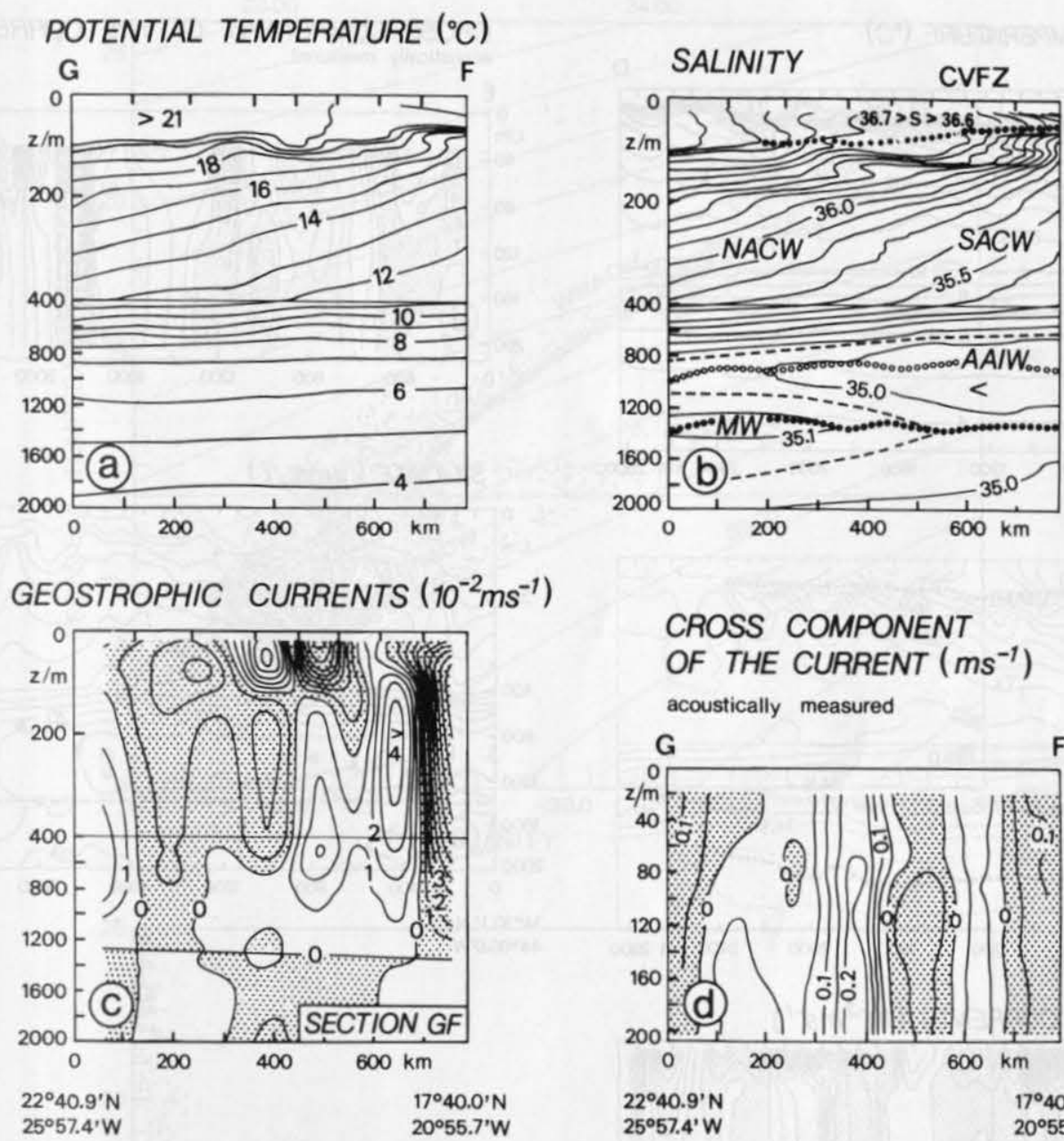

\section{CROSS COMPONENT OF THE CURRENT $\left(\mathrm{ms}^{-1}\right)$}

acoustically measured

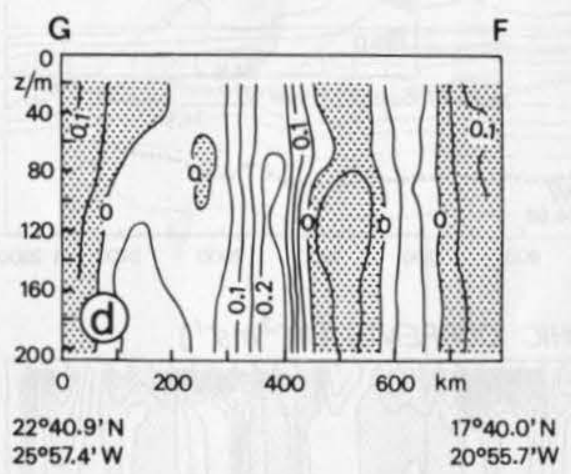

Fig. 5. Hydrographic section GF. Also included are characteristic water masses: North and South Atlantic Central Water, Antarctic Intermediate Water, and Mediterranean Water. (a) Potential temperature. (b) Salinity. Solid dots point out the salinity maximum and open circles show the minimum. Note that the dashed line is the additional isohaline $S=35.05$ (Cape Verde Frontal Zone). (c) Geostrophic currents. Contour interval is $1 \mathrm{~cm} \mathrm{~s}^{-1}$. (d) Acoustically measured velocity component perpendicular to the section. Contour interval is $0.05 \mathrm{~m} \mathrm{~s}^{-1}$. Shaded regions in Figures $5 c$ and $5 d$ indicate currents coming out of the picture.

$(34.98<S<35.00)$ are clearly below those of section GF farther north (see Figure $5 b$ ).

To compute the geostrophic flow perpendicular to section ED (Figure $6 c$ ), the level of no motion is determined by relation (1) to be approximately $1400 \mathrm{~m}$. Near-surface jets dominate the velocity field to a depth of $100 \mathrm{~m}$. Deeperreaching signals are found in four cases only. In the first case, between kilometers 1600 and 1900 , west of the Cape Verde archipelago, is a deep $(1100 \mathrm{~m})$ reaching southward current which is fresher, colder, and richer in silicate than its surroundings. Between kilometer 1900 and 2200 at the longitude of the Cape Verde Islands the same water mass, i.e. South Atlantic Central Water, is carried by an equally deep current to the north. Third, between the islands (kilometer 2500 ) and the African shelf (kilometer 2700), lies a strong northward flow, extending to just $400-\mathrm{m}$ depth. Here also South Atlantic Central Water is transported to the north. Finally, between kilometers 2700 and 2800 , next to the coast, there is a southward boundary current with a speed of $0.1 \mathrm{~m}$ $\mathrm{s}^{-1}$ at the surface and $0.02 \mathrm{~m} \mathrm{~s}^{-1}$ at a depth of $200 \mathrm{~m}$.

For comparison within the upper $200 \mathrm{~m}$, Figure $6 d$ shows the acoustically measured north-south velocity component across the east-west section ED. These data are likewise interpolated on a grid with $30-\mathrm{km}$ spacing. Because of the noisier nature of the acoustic data, they are slightly smoothed for the purpose of graphical representation; however, the large-scale structure is preserved. There are only a few similarities between the directly observed and the geostrophic flow field, e.g., the region around the Cape Verde archipelago. This poor correlation is not very surprising for two reasons. First, the estimated errors due to inaccurate ship positioning are often as large as the observed velocity. Second, the ADCP signal includes ageostrophic current components. Between the archipelago and the continent, the ADCP measures a northward flow which subsides quickly toward the coast. The observed southward geostrophic boundary current is missed by the ADCP observations, which is a result of the aforementioned smoothing procedure. But this current is conspicuous in the horizontal map of the acoustically measured velocity field which uses interpolated but unsmoothed vectors (Figure $8 d$ ).

To check the validity of Stramma's [1984] 1400-dbar level of no motion in the south, we use the ADCP data and geostrophic profiles along section ED. Between the CTD 


\section{POTENTIAL TEMPERATURE $\left({ }^{\circ} \mathrm{C}\right)$}

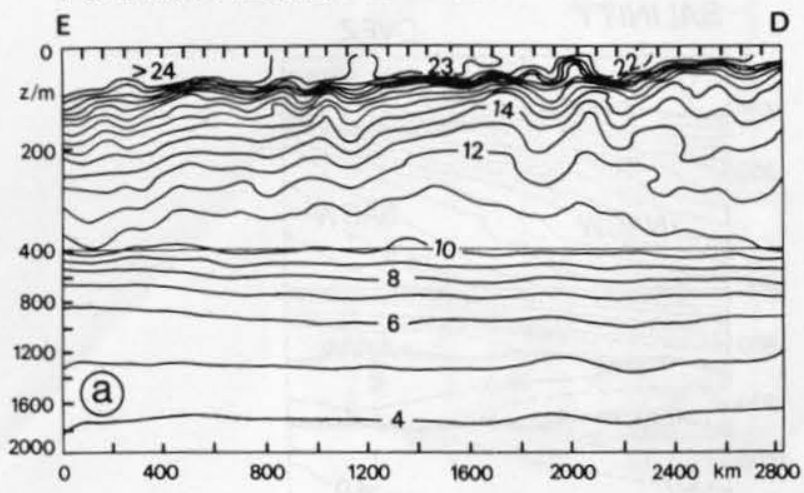

SALINITY

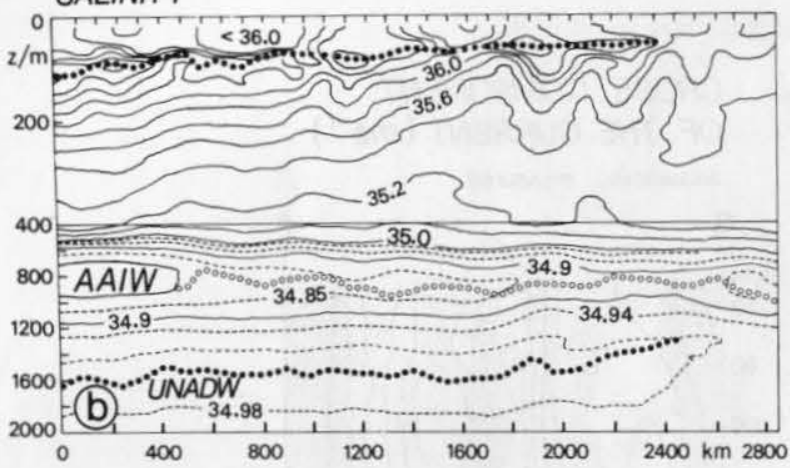

CROSS COMPONENT OF THE CURRENT $\left(\mathrm{ms}^{-1}\right)$ acoustically measured

E

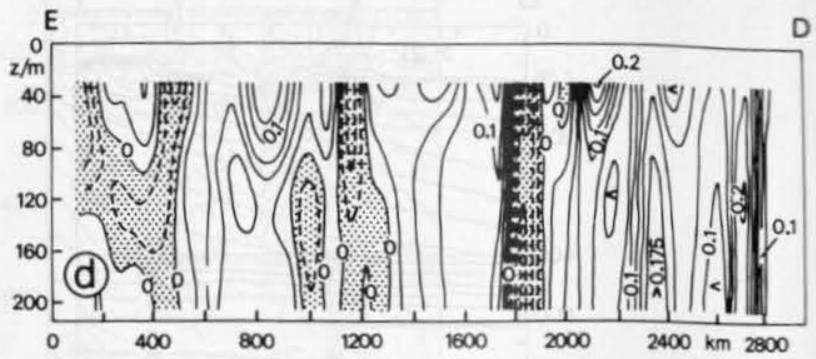

SILICATE $(\mu \mathrm{mol} / \mathrm{l})$

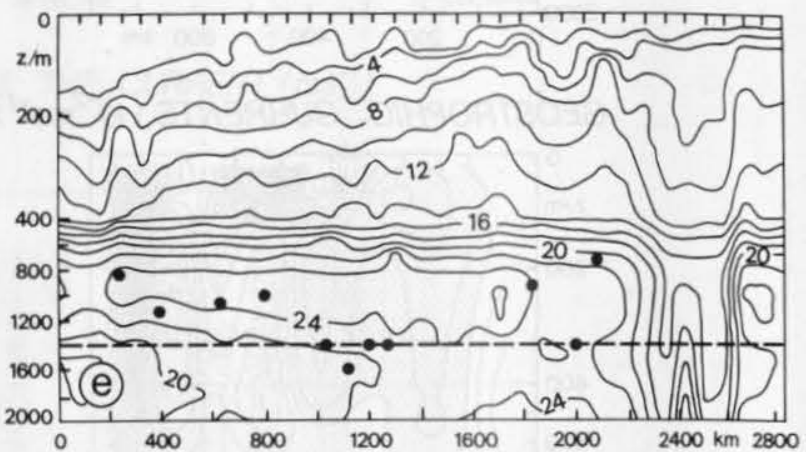

$14^{\circ} 30.1 ' \mathrm{~N}$

$44^{\circ} \mathrm{O0.0} \mathrm{O}^{\prime W} \mathrm{~W}$

GEOSTROPHIC CURRENTS $\left(10^{-2} \mathrm{~ms}^{-1}\right)$

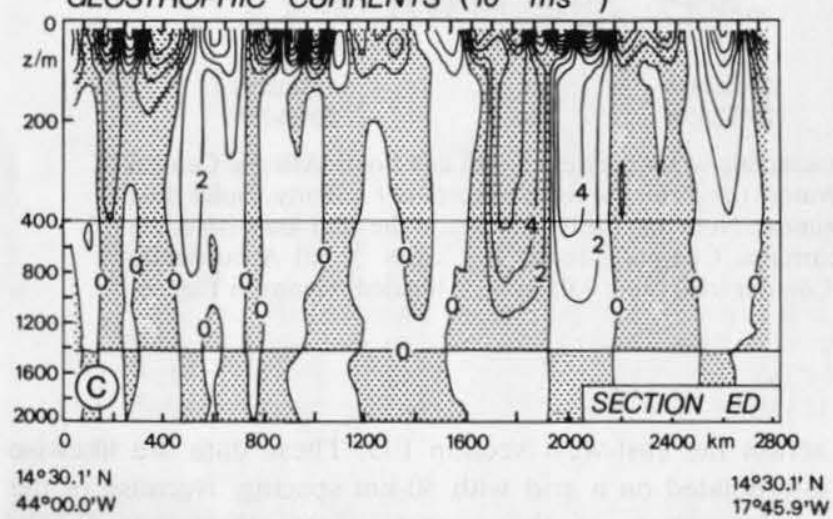

Fig. 6. Hydrographic section ED. (a) Potential temperature. (b) Salinity with core layers (extrema). (c) Geostrophic currents. (d) Acoustically measured velocity component perpendicular to the section. Shaded regions in Figures $4 c$ and $4 d$ indicate currents coming out of the picture. (e) Silicate (courtesy of B. Klein). The dashed line labels the level of no motion according to Figure $1 b$. Dots represent the reference level inferred from ADCP data.

casts, $\sim 85 \mathrm{~km}$ apart, numerous ADCP current profiles with a mean spacing of $30 \mathrm{~km}$ are available (see Figure $8 d$ ). First, the cross component relative to the ship track (here, the north-south component, $v$ ) of the absolute ADCP currents is averaged between neighboring CTD stations. Next, ADCP currents and the geostrophic velocity relative to $1400 \mathrm{~m}$ are vertically averaged between $160 \mathrm{~m}$ and $220 \mathrm{~m}$. We choose $160 \mathrm{~m}$ as a minimum depth to keep clear of ageostrophic effects near the surface. The lower limit is prescribed by the depth range of the ADCP. The calculated differences between directly measured currents and geostrophic velocities relative to $1400 \mathrm{~m}$ were used to apply a barotropic correction to each geostrophic current profile [Smith and Morrison, 1989], where ADCP data are based on good navigation data and where no significant horizontal gaps before interpolation on the $30-\mathrm{km}$ grid occur. In some cases, these corrections are so large that no level of no motion could be found, especially between the Cape Verde Islands and the continent. But there remain also some examples of acoustically determined levels of no motion. These are marked by dots in the silicate section (Figure $6 e$ ) and at least do not contradict either the classical water mass criterion of defining the zero velocity level or Stramma's [1984] 1400-dbar level of no motion at $14.5^{\circ} \mathrm{N}$.

\section{Large-Scale Property Distributions}

From the discussion of sections it appears convenient to discuss the large-scale property distributions layer by layer, beginning at the surface. Figure 8 displays the winter prop- 

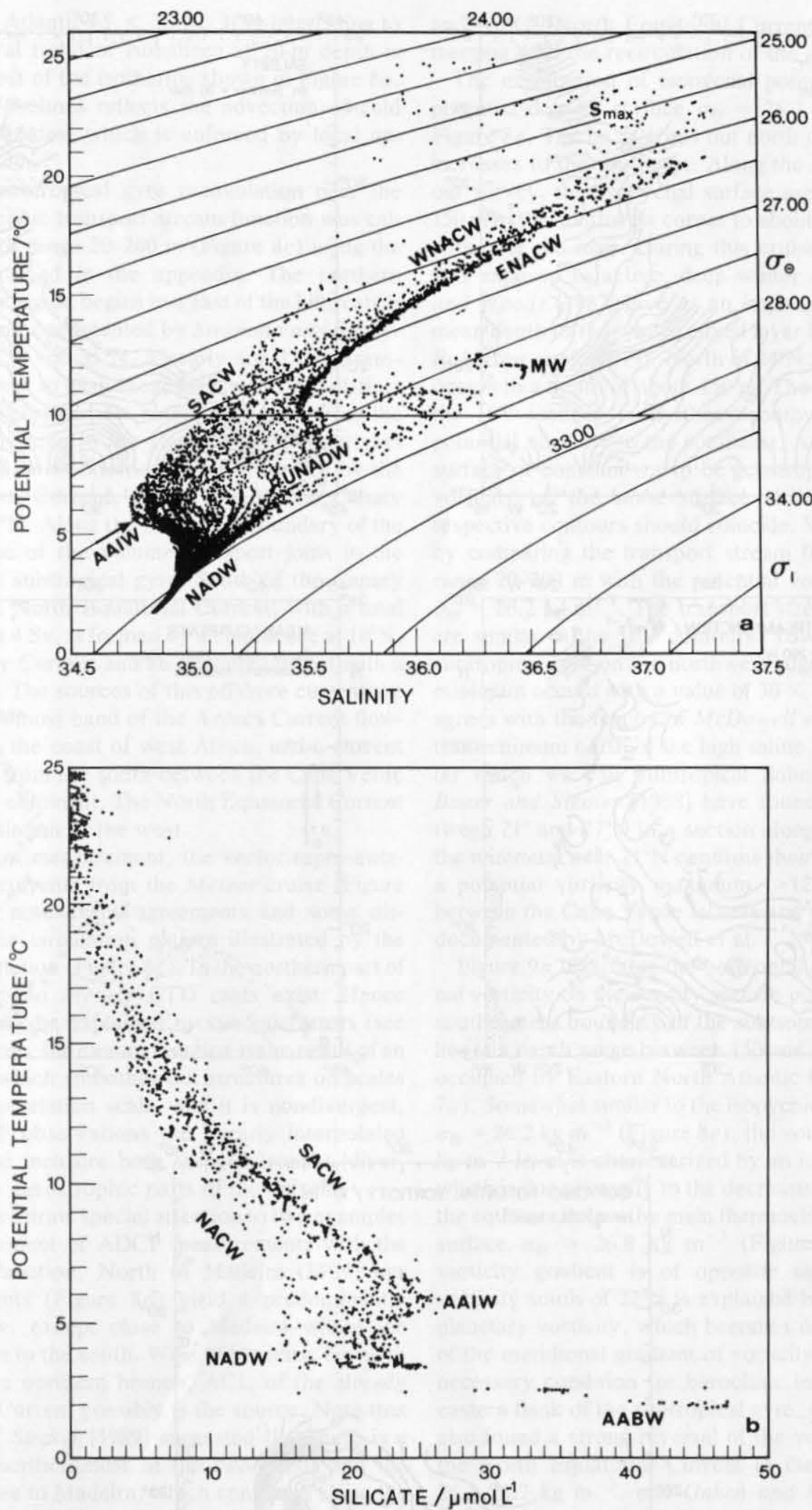

Fig. 7. (a) Potential temperature-salinity diagram including the main water masses (see text) on the basis of measurements from the FS Meteor 9 and R/V Arnold Veimer 27 cruises. Also shown are isopycnal lines (kilograms per cubic meter) referenced to the surface $\left(\sigma_{\Theta}\right)$ and to $1000 \mathrm{dbar}\left(\sigma_{1}\right)$. (b) Potential temperature-silicate diagram of the main water masses on the basis of FS Meteor 9 measurements (courtesy of B. Klein).

erty distribution in the upper ocean of the southeastern corner of the subtropical gyre. The edge of the subtropical gyre is recognized by the arch-shaped isohalines (e.g., 37.0 in Figure $8 b$ ). The center values of $>37.2$ are due to high evaporation rates under the northeast trades. The picture is more complicated farther east, where cold, low-salinity water is upwelled off Cape Blanc. The salinity of the southern edge of the gyre is governed by the high precipita- 

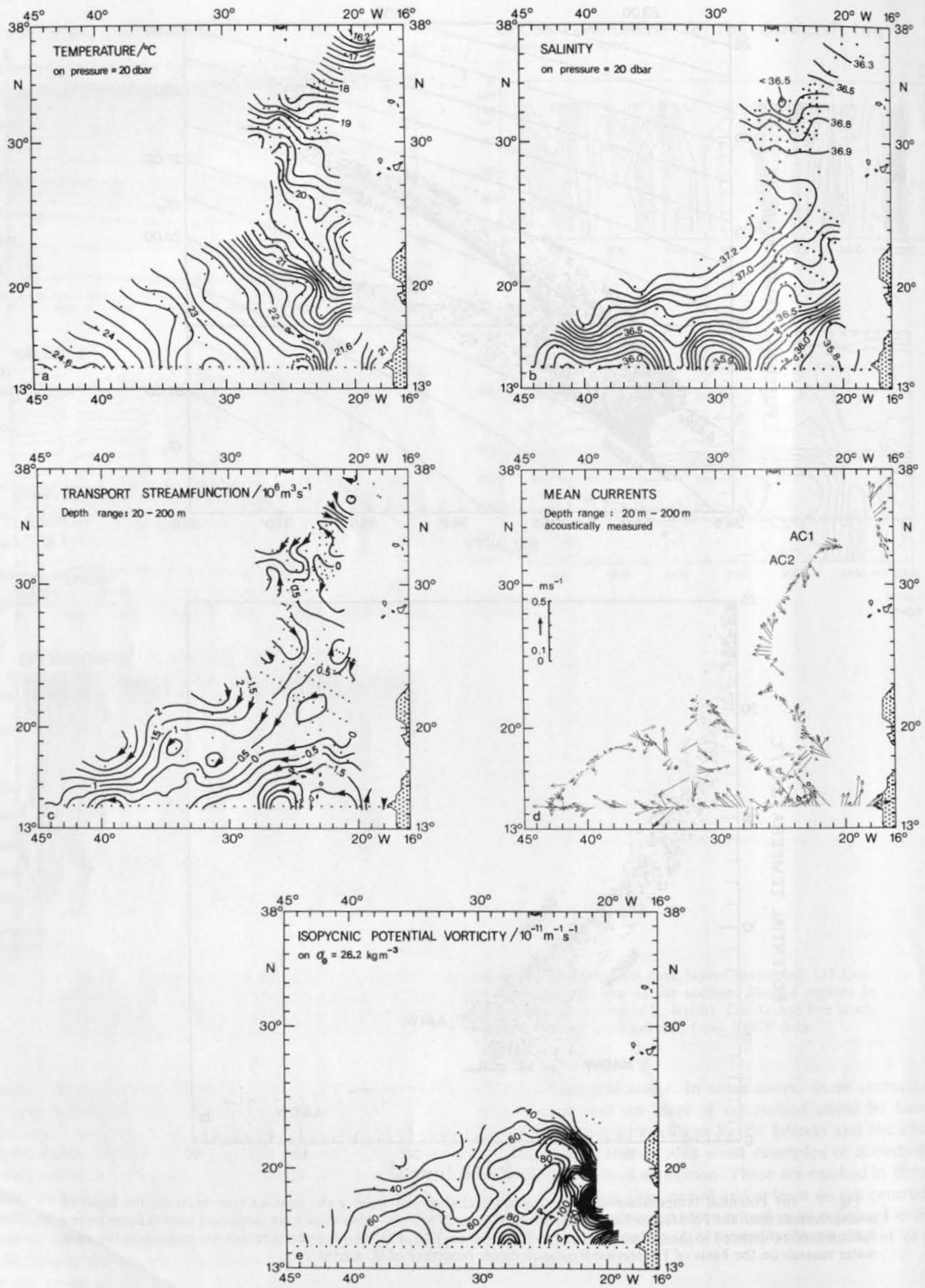

Fig. 8. Horizontal distributions of $(a)$ temperature at 20 dbar (contour interval, $0.2 \mathrm{~K}$ ), $(b)$ salinity at 20 dbar (contour interval, 0.1), (c) transport stream function for the depth range $20-200 \mathrm{~m}$ (contour interval, $0.5 \times 10^{6} \mathrm{~m}^{3} \mathrm{~s}^{-1}$ ), $(d)$ acoustically measured currents for the depth range $20-200 \mathrm{~m}$, and $(e)$ isopycnic potential vorticity on the density surface $\sigma_{\Theta}=26.2 \mathrm{~kg} \mathrm{~m}^{-3}$ (contour interval, $10 \times 10^{-11} \mathrm{~m}^{-1} \mathrm{~s}^{-1}$ ). 
tion in the tropical Atlantic $(S<36.3)$. It is interesting to note that the general trend of isohalines at $20-\mathrm{m}$ depth is perpendicular to most of the isotherms shown in Figure $8 a$. This orientation of isolines reflects the advection of cold water from high latitudes, which is enforced by local upwelling off Mauretania.

To present the subtropical gyre recirculation near the surface, the geostrophic transport stream function was calculated for the depth range $20-200 \mathrm{~m}$ (Figure $8 c$ ) using the approximation described in the appendix. The northern corner of our survey region begins just east of the bifurcation of the Azores Current documented by Stramma and Siedler [1988]. Between $33^{\circ} \mathrm{N}$ and $35^{\circ} \mathrm{N}$, a nearly zonal flow transports $2.5 \mathrm{~Sv}$ from west to east. Near $33^{\circ} \mathrm{N}$ a second, distinct current with a transport of $1 \mathrm{~Sv}$ enters the region from the north and leaves the area to the southwest. Both currents can be traced to the two easternmost bands formed by the branching of Azores Current, which lead to the Canary Current south of $27^{\circ} \mathrm{N}$. Along the northwest boundary of the survey, each isoline of the volume transport joins in the recirculation of the subtropical gyre. South of the Canary Current region, the North Equatorial Current, with a total transport of roughly $4 \mathrm{~Sv}$, is formed by a confluence at $18^{\circ} \mathrm{N}$, $23^{\circ} \mathrm{W}$, of the Canary Current and an offshore current with a transport of $1.5 \mathrm{~Sv}$. The sources of this offshore current are probably the easternmost band of the Azores Current flowing southward near the coast of west Africa, and a current entering the region from the south between the Cape Verde archipelago and the continent. The North Equatorial Current completes the circulation to the west.

As an independent measurement, the vector representation of the ADCP currents from the Meteor cruise (Figure $8 d$ ) shows several noteworthy agreements and some disagreements with the circulation pattern illustrated by the transport stream function (Figure $8 c$ ). In the northern part of the surveyed area, no Meteor CTD casts exist. Hence differences there may be explained by synoptic errors (see Table 1). Furthermore, the stream function is the result of an objective analysis which smoothes out structures on scales smaller than the correlation scale, and it is nondivergent, whereas the ADCP observations are linearly interpolated along the track and measure both the geostrophic (divergence-free) and the ageostrophic parts of the current.

In the following we draw special attention to two examples of the partial agreement of ADCP measurements with the transport stream function. North of Madeira $\left(34^{\circ} \mathrm{N}\right)$ our ADCP measurements (Figure $8 d$ ) yield a predominantly northeastward flow, except close to Madeira where the current vectors turn to the south. West of Madeira, between $30^{\circ} \mathrm{N}$ and $33^{\circ} \mathrm{N}$, the northern branch, $\mathrm{ACl}$, of the already bifurcated Azores Current possibly is the source. Note that recently Klein and Siedler [1989] suggested that there is a link between the northernmost of the two bands and the southward flow close to Madeira, which continues along the west African coast and ends in the Canary Current.

Another distinct current flowing into the survey region is exposed by the ADCP between the Cape Verde Islands and the African coast. The acoustic measurements confirm the pattern of the transport stream function around the Cape Verde archipelago. Part of this flow branches off north of the islands and intensifies the westward transport. This flow has recently been modeled by Spall [1990]. His analysis also shows a current entering the region at $15^{\circ} \mathrm{N}$ between $30^{\circ} \mathrm{W}$ and Africa (North Equatorial Current in his notation) and merging with the recirculation of the subtropical gyre.

The distribution of isopycnal potential vorticity on the potential density surface $\sigma_{\Theta}=26.2 \mathrm{~kg} \mathrm{~m}^{-3}$ is shown in Figure $8 e$. The layer crops out north of $24^{\circ} \mathrm{N}$, and its depth increases to the southeast. Along the southern boundary of our survey, this isopycnal surface ascends from a depth of $150 \mathrm{~m}$ in the southwest corner to about $70 \mathrm{~m}$ in the southeast corner of the map. During this cruise this density surface was exposed to active, deep winter convection. Stammer and Woods [1987] give us an impression of the maximum mean depth of the winter mixed layer based on atlas data by Robinson et al. [1979]. North of $24^{\circ} \mathrm{N}$ the winter convection occurs to a depth of about $150 \mathrm{~m}$. The general orientation of the IPV isolines is northeast-southwest, with increasing potential vorticity to the southeast. Assuming the flow on a surface of constant $\sigma_{\Theta}$ to be geostrophic and the potential vorticity on the same surface to be conservative, their respective contours should coincide. We find this confirmed by comparing the transport stream function for the depth range $20-200 \mathrm{~m}$ with the potential vorticity distribution on $\sigma_{\Theta}=26.2 \mathrm{~kg} \mathrm{~m}^{-3}$. The transport streamlines west of $25^{\circ} \mathrm{W}$ are similar to the IPV contours. Toward the center of the subtropical gyre on the northwest edge of the survey area, a minimum occurs with a value of $30 \times 10^{-11} \mathrm{~m}^{-1} \mathrm{~s}^{-1}$, which agrees with the results of $M c$ Dowell et al. [1982]. They find this minimum north of the high saline Subtropical Underwater which we call Subtropical Salinity Maximum Water. Bauer and Siedler [1988] have found this water mass between $21^{\circ}$ and $27^{\circ} \mathrm{N}$ in a section along $33^{\circ} \mathrm{W}$. Our finding of the minimum near $21^{\circ} \mathrm{N}$ confirms theirs. In contrast, there is a potential vorticity maximum $\left(>120 \times 10^{-11} \mathrm{~m}^{-1} \mathrm{~s}^{-1}\right)$ between the Cape Verde Islands and the African shelf, also documented by McDowell et al.

Figure $9 a$ illustrates the horizontal distribution of isopycnal vorticity on the density surface $\sigma_{\Theta}=26.6 \mathrm{~kg} \mathrm{~m}^{-3}$ at the southeastern boundary of the subtropical gyre. This surface lies in a depth range between 150 and $250 \mathrm{~m}$ which is largely occupied by Eastern North Atlantic Central Water (Figure $7 a$ ). Somewhat similar to the isopycnic potential vorticity on $\sigma_{\Theta}=26.2 \mathrm{~kg} \mathrm{~m}^{-3}$ (Figure $8 e$ ), the vorticity at the $\sigma_{\Theta}=26.6$ $\mathrm{kg} \mathrm{m}^{-3}$ level is characterized by an increase south of $20^{\circ} \mathrm{N}$, which is due primarily to the decreasing stratification toward the equator. Below the main thermocline on a deeper density surface $\sigma_{\Theta}=26.8 \mathrm{~kg} \mathrm{~m}^{-3}$ (Figure $9 b$ ), the meridional vorticity gradient is of opposite sign. This decrease in vorticity south of $22^{\circ} \mathrm{N}$ is explained by equatorward loss of planetary vorticity, which becomes dominant. The reversal of the meridional gradient of vorticity with depth yields the necessary condition for baroclinic instability at the southeastern flank of the subtropical gyre. McDowell et al. [1982] also found a strong reversal of the vorticity gradient below the North Equatorial Current in the density range $\sigma_{\Theta}=$ 26.3-26.7 kg m $\mathrm{m}^{-3}$, and Onken and Klein [1991] explained observed current variability in that area partially by modeled baroclinic instability.

From Käse et al. [1986], we adopt the choice of $560 \mathrm{~m}$ as a representative level for the central water distribution. Figure 10 shows maps of horizontal temperature (Figure $10 a$ ) and salinity (Figure $10 b$ ) distributions. In contrast to our near-surface pictures in Figure 8 , and because of the close $\Theta / S$ relationship of central waters seen in Figure $7 a$, we find nearly congruent distributions of temperature and 

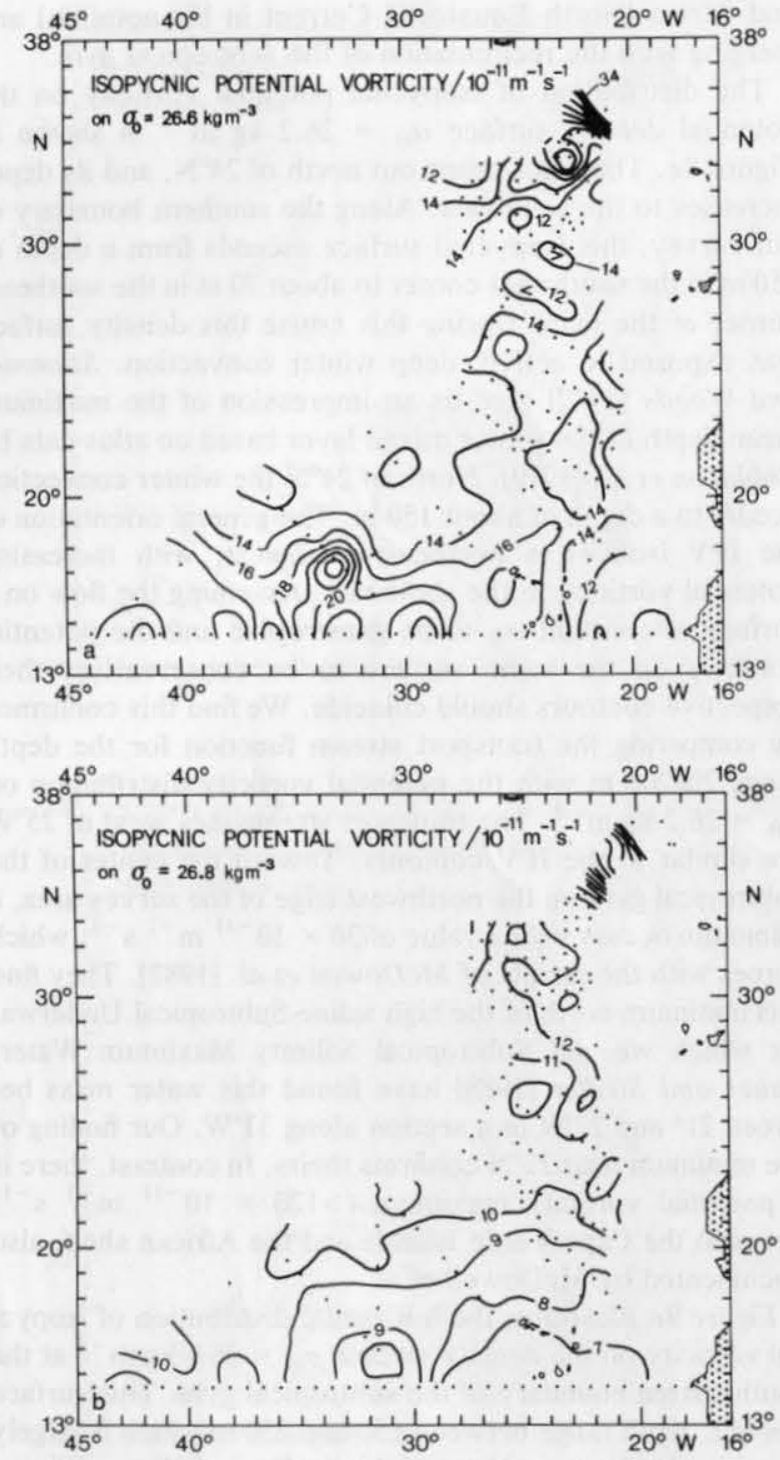

Fig. 9. Horizontal distributions of isopycnic potential vorticity (a) on $\sigma_{\Theta}=26.6 \mathrm{~kg} \mathrm{~m}^{-3}$ (contour interval, $2 \times 10^{-11} \mathrm{~m}^{-1} \mathrm{~s}^{-1}$ ) and (b) on $\sigma_{\Theta}=26.8 \mathrm{~kg} \mathrm{~m}^{-3}$ (contour interval, $1 \times 10^{-11} \mathrm{~m}^{-1} \mathrm{~s}^{-1}$ ).

salinity. The southern part of both maps is governed by strong meridional gradients. South Atlantic Central Water and North Atlantic Central Water compete with each other in this area. As expected, we find weak gradients at the latitude of the Canary Islands $\left(\sim 28^{\circ} \mathrm{N}\right)$. The characteristic Eastern North Atlantic Central Water in that region and at that level shows minimal horizontal gradients.

Contrary to the upper $200 \mathrm{~m}$, the transport stream function in the layer between 200 and $700 \mathrm{~m}$ (Figure 10c) is characterized by the eddy field south of $28^{\circ} \mathrm{N}$. The indistinct flow field contains no indications of the Canary Current or the North Equatorial Current, from which we conclude that both currents are restricted to the upper $200 \mathrm{~m}$. Quite different is the situation in the case of the Azores Current. Here we find a continuous meander with a significant transport of 2-3 Sv in the depth range $200-700 \mathrm{~m}$. Owing to the broader range of integration, the aforementioned anticyclonic eddy centered at $25.5^{\circ} \mathrm{W}$ and $26^{\circ} \mathrm{N}$ now appears more clearly than in the layer above. This anticyclone is also verified by its surface signal in the ADCP currents in Figure $8 d$.
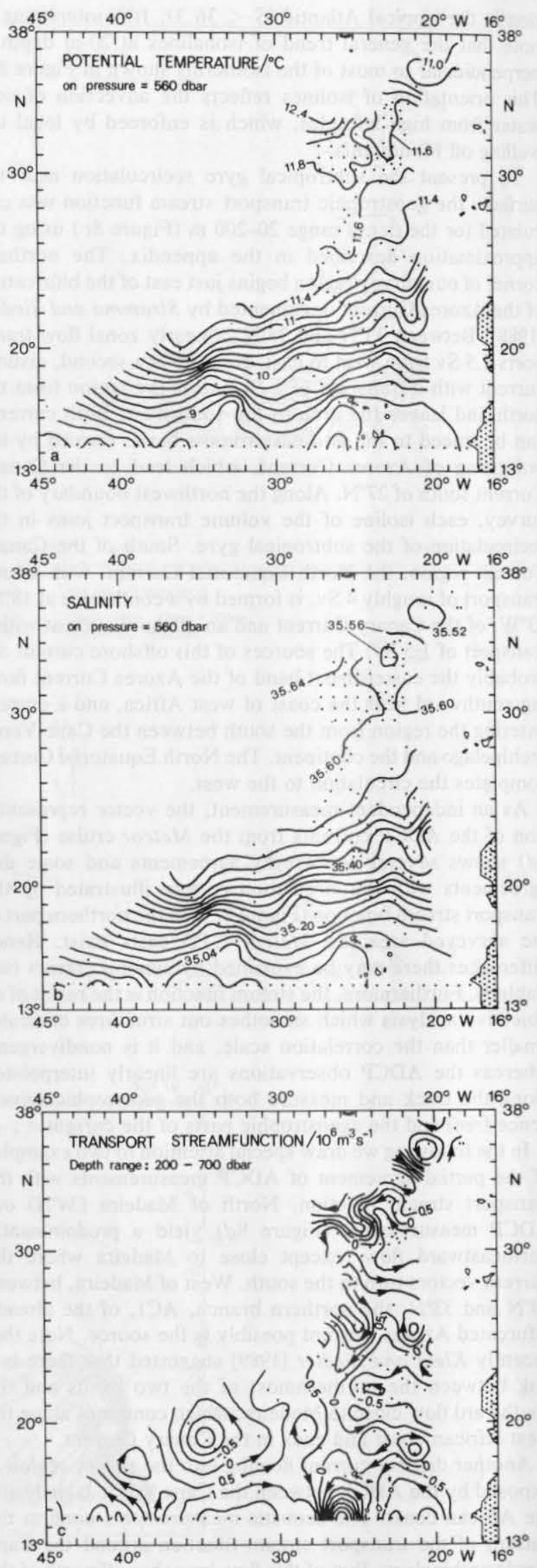

Fig. 10. Horizontal distributions of $(a)$ potential temperature at $560 \mathrm{dbar}$ (contour interval, $0.2 \mathrm{~K}$ ), $(b)$ salinity at $560 \mathrm{dbar}$ (contour interval, 0.04), and (c) transport stream function for the depth range $200-700 \mathrm{dbar}$ (contour interval, $0.5 \times 10^{6} \mathrm{~m}^{3} \mathrm{~s}^{-1}$ ). 
Assuming that water masses spread along isopycnal surfaces on large scales, two density levels are selected to discuss the distribution of Antarctic Intermediate Water and Mediterranean Water. Figure $11 a$ displays a map of the salinity distribution at $\sigma_{1}=31.9 \mathrm{~kg} \mathrm{~m}^{-3}$ which, according to the $\Theta S$ diagram (Figure 7a), is a representative layer for the Antarctic Intermediate Water. The zonal alignment and general northward trend of increasing salinity has already been seen in the thermocline (Figure $10 \mathrm{~b}$ ). As Zenk et al. [1991] have shown, the Cape Verde Frontal Zone not only separates the two characteristic central water masses but also marks a second "front" beneath the thermocline.

The opponent of Antarctic Intermediate Water is the Mediterranean Water with slightly higher density, $\sigma_{1}=$ $32.10 \mathrm{~kg} \mathrm{~m}^{-3}$, penetrating from the northeast. The map in Figure $11 b$ shows the salinity decrease of the Mediterranean Water tongue to the south consistent with advection. North of the Canary Islands $\left(\sim 28^{\circ} \mathrm{N}\right)$, isohalines are more zonally oriented. Further south they turn clockwise, lying orthogonal to the near-surface salinity distribution seen in Figure $8 b$. At the southern margin of Figure 11 the meridional gradient is weak. A comparison with Figure $5 b$ shows that the intermediate salinity maximum at $34.98<S<35.00$ is situated slightly beneath the displayed density surface $\sigma_{1}=$ $32.10 \mathrm{~kg} \mathrm{~m}^{-3}$ at a pressure of $\sim 1660 \mathrm{dbar}$.

In addition to the large-scale features shown in the Mediterranean Water level there is an isolated, well-resolved, salty lens in Figure $11 b$ at $22^{\circ} \mathrm{N}, 25^{\circ} \mathrm{W}$, with a salinity maximum of $S=35.25$. The position of the lens, found by A. Veimer in February 1989, is nearly identical with the observation site of meddy "Birgit" found at $22^{\circ} \mathrm{N}, 26^{\circ} \mathrm{W}$, by Meteor in November 1986 [Zenk et al., 1991].

The meandering Azores current is more weakly developed between 700 and $1200 \mathrm{~m}$ than between 200 and $700 \mathrm{~m}$, but the shape of the meander in both layers is nearly congruent. In the south, the lack of distinct orientation of the stream function in the upper thermocline $(200-700 \mathrm{~m}$; Figure $10 \mathrm{c}$ ) is replaced by a clear alignment of eastward flow in the lower layer $(700-1200 \mathrm{~m})$. Taking the horizontal distribution of salinity on the isopycnal $\sigma_{1}=31.9 \mathrm{~kg} \mathrm{~m}^{-3}$ into consideration, this circulation pattern suggests that Antarctic Intermediate Water enters this region from the west between $15^{\circ} \mathrm{N}$ and $20^{\circ} \mathrm{N}$ with an eastward transport of $2 \mathrm{~Sv}$ at $35^{\circ} \mathrm{W}$.

\section{Discussion and Conclusions}

In order to examine the thermocline circulation and water masses in the Canary basin, extensive measurements were carried out using CTDs, XBTs and a shipborne ADCP. Our stream function analysis assumes geostrophic balance, which leads to an underestimate of total transports, especially for the North Equatorial Current regime. Maillard and Käse [1989] have investigated the near-surface flow in the subtropical gyre mainly with surface drifter data. They point out that the North Equatorial Current is largely ageostrophic owing to the direct influence of the trade winds, while the Azores Current is nearly geostrophically balanced. Errors in the acoustic current measurements due to inaccurate ship position prevented us from an alternative transport calculation using the $\mathrm{ADCP}$.

Synthesizing all available data of our survey, we construct a three-layer scenario (Figure 12). In the upper layer between the sea surface and $200-\mathrm{m}$ depth, a nearly complete
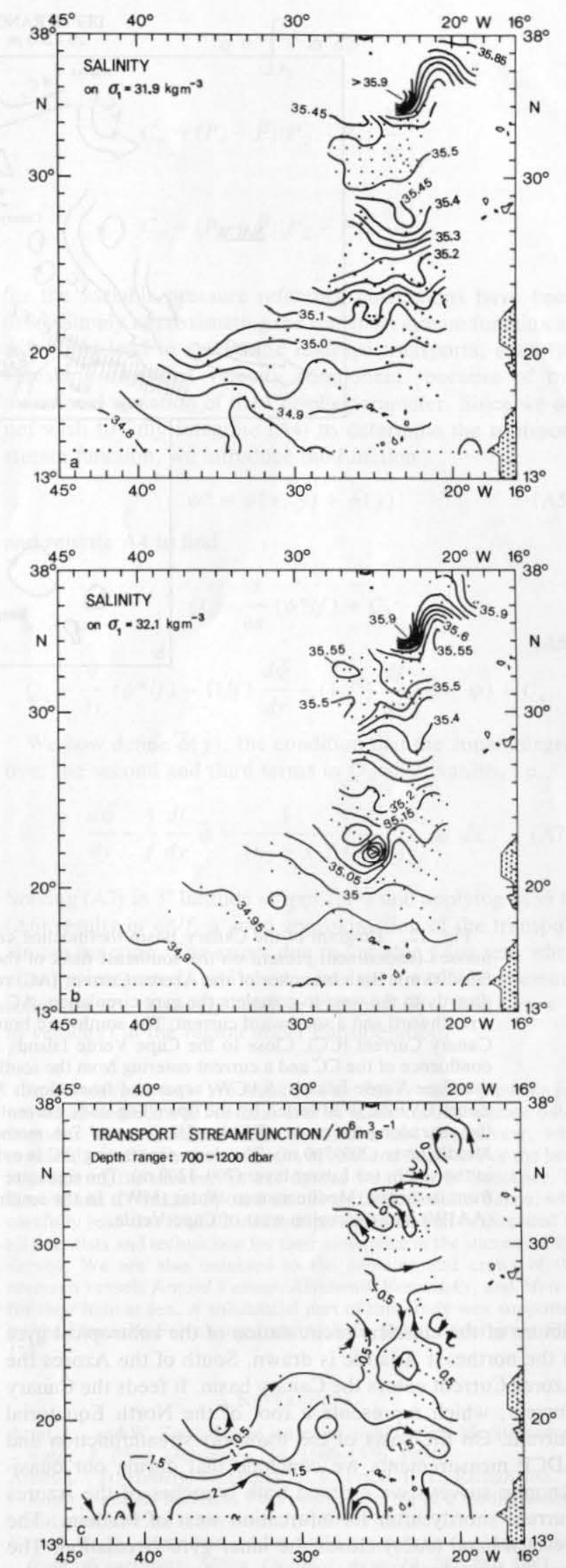

Fig. 11. Horizontal distributions of $(a)$ salinity on $\sigma_{1}=31.9 \mathrm{~kg}$ $\mathrm{m}^{-3}$ at the density level of Antarctic Intermediate Water (contour interval, 0.05), (b) salinity on $\sigma_{1}=32.1 \mathrm{~kg} \mathrm{~m}^{-3}$ at the density level of Mediterannean Water (contour interval 0.05), and (c) transport stream function $700-1200 \mathrm{dbar}$ (contour interval, $0.5 \times 10^{6} \mathrm{~m}^{3} \mathrm{~s}^{-1}$ ). 


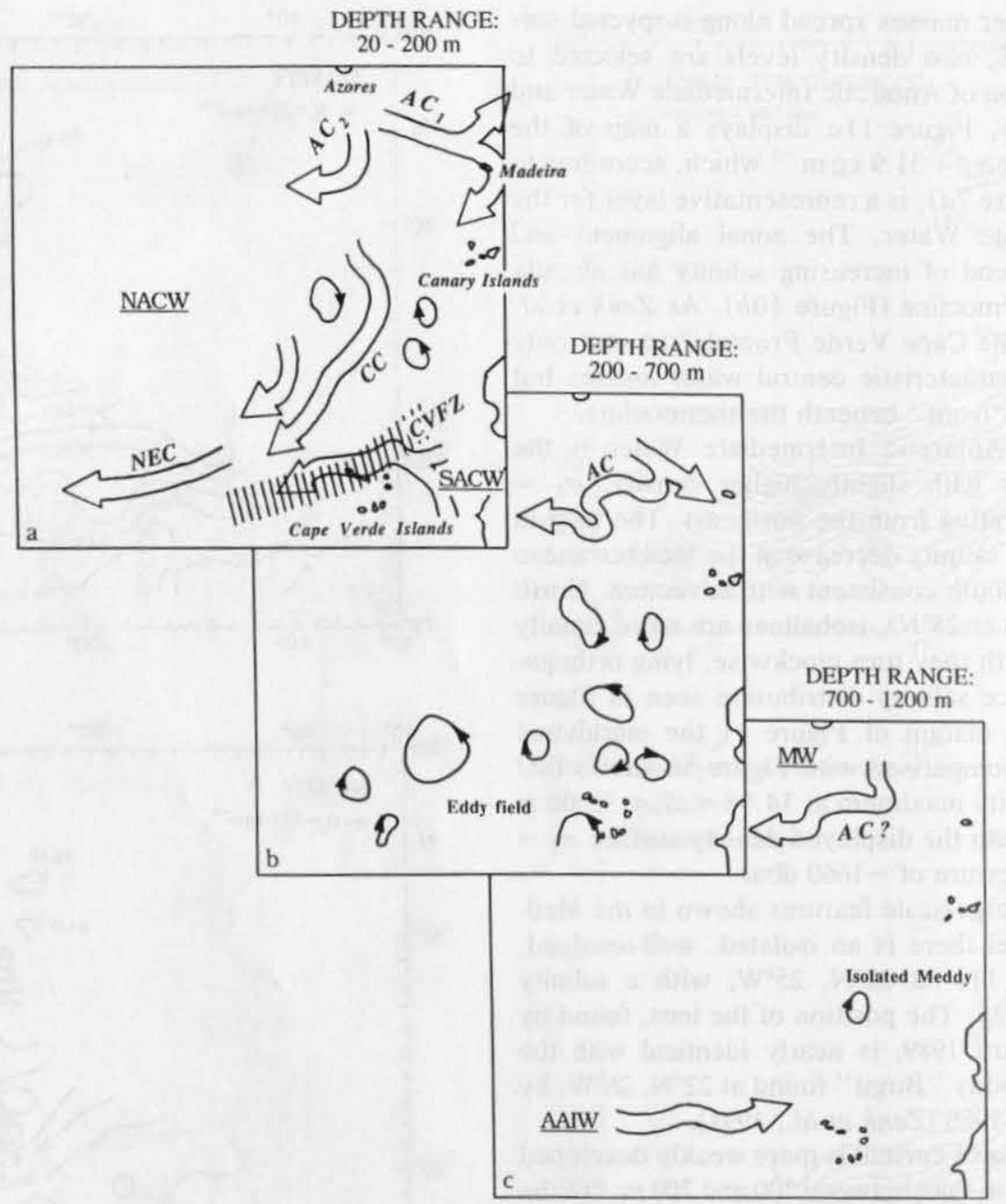

Fig. 12. Diagram of the Canary Basin thermocline circulation, showing the major currents (italic) and the water masses (underlined) present on the southeast flank of the subtropical gyre for three defined layers. $(a)$ Upper layer $(20-200 \mathrm{~m})$. Both branches of the Azores Current $(\mathrm{AC})$ result from its bifurcation west of Madeira. While $\mathrm{AC}_{2}$ turns directly to the west to complete the gyre circulation, $\mathrm{AC}_{1}$ flows to the east, splitting once more north of Madeira into a northward and a southward current. The southward branch circulates anticyclonically around Madeira and feeds the Canary Current (CC). Close to the Cape Verde Islands the North Equatorial Current (NEC) rises mainly from the confluence of the CC and a current entering from the south and carrying South Atlantic Central Water (SACW) around the Cape Verde Islands. SACW, separated from North Atlantic Central Water (NACW) by the Cape Verde Frontal Zone (CVFZ), is advected by the upwelling undercurrent northward across the equator and can be found throughout the year along the coast off Dakar [Hagen and Schemainda, 1989]. The mean flow is disturbed by the eddy field. $(b)$ Middle layer $(200-700 \mathrm{~m})$. The deep penetrating AC is evident at the northern edge, whereas an eddy field dominates in the south. $(c)$ Lower layer $(700-1200 \mathrm{~m})$. The signature of the $\mathrm{AC}$ fades out and an isolated meddy is found far away from its origin, Mediterranean Water (MW). In the south, an eastward flow transports Antarctic Intermediate Water (AAIW) into the region west of Cape Verde.

picture of the classical recirculation of the subtropical gyre in the northeast Atlantic is drawn. South of the Azores the Azores Current enters the Canary basin. It feeds the Canary Current, which represents a root of the North Equatorial Current. On the basis of the transport streamfunction and ADCP measurements we conclude that during our quasisynoptic surveys we crossed both branches of the Azores Current shortly after its bifurcation west of Madeira. The western band $\left(\mathrm{AC}_{2}\right)$ closes the inner gyre circulation. The eastern branch $\left(\mathrm{AC}_{1}\right)$ contributes to the near-shelf circulation. North of Madeira, $\mathrm{AC}_{1}$ branches southward and northward. The northward branch of $\mathrm{AC}_{1}$ has already been described by Käse et al. [1986]. They suspect that a part of this current returns to the south via the Portugal Current.
South of $20^{\circ} \mathrm{N}$, all branches originating from the Azores Current and the current entering the region from the south between Cape Verde and Africa, converge and form the North Equatorial Current. Roughly $4 \mathrm{~Sv}$ is recirculated between $14.5^{\circ} \mathrm{N}$ and $22^{\circ} \mathrm{N}$ at $30^{\circ} \mathrm{W}$; the contribution of the current from the south to the confluence amounts to approximately $1 \mathrm{~Sv}$, estimated along $14.5^{\circ} \mathrm{N}$ between the Cape Verde Islands and the shelf off Dakar, Senegal.

South Atlantic Central Water was observed north of $14.5^{\circ} \mathrm{N}$. It appears that this water mass penetrates into the survey area through the passage between the Cape Verde Islands and the African continent. The northward advection of South Atlantic Central Water occurs in narrow intrusions governed by strong currents. These jets form a cyclonic 
circulation around the Cape Verdes documented by the stream function (Figure $8 c$ ) and supported by the acoustically measured currents (Figure $8 d$ ).

The Azores Current is the only deep-reaching current in the layer between 200 and $700 \mathrm{~m}$. It has a transport of $7 \mathrm{~Sv}$ and enters the study region from the west. At this depth, as opposed to the upper $200 \mathrm{~m}$, the Canary Current and the North Equatorial Current are absent. Instead, the southern part of the region is populated by mesoscale eddies. These features are consistent with the distribution of potential vorticity and the theory of baroclinic instability.

In the lower layer, $700-1200 \mathrm{~m}$, the Azores Current fades out. A few isolated meddies are found in the center of the region. At $35^{\circ} \mathrm{N}$ an eastward current carries $2 \mathrm{~Sv}$ of Antarctic Intermediate water into the region west of the Cape Verde Islands.

\section{APPENDIX: Approximation of THE Geostrophic Transport Stream Function}

From the geostrophic and hydrostatic equations, one derives the geostrophic northward and eastward velocity components:

$$
\begin{aligned}
& v=-\frac{1}{f} \int_{P}^{P_{r}} \frac{\partial \delta}{\partial x} d p \\
& u=\frac{1}{f} \int_{P}^{P,} \frac{\partial \delta}{\partial y} d p .
\end{aligned}
$$

Here $x$ and $y$ are eastward and northward directions, $f$ is the variable Coriolis parameter, $\delta$ is the specific volume anomaly, and $P_{r}$ is a horizontally varying pressure reference level with vanishing geostrophic flow. Introducing $\bar{P}$ as a constant approximation of $P_{r}$, equations (A1) are rewritten,

$$
\begin{gathered}
v=-\frac{1}{f}\left(\frac{\partial \phi}{\partial x}+\left.\left(P_{r}-\bar{P}\right) \frac{\partial \delta}{\partial x}\right|_{P_{r}}\right) \\
u=\frac{1}{f}\left(\frac{\partial \phi}{\partial y}+\left.\left(P_{r}-\bar{P}\right) \frac{\partial \delta}{\partial y}\right|_{P_{r}}\right)
\end{gathered}
$$

with the definition

$$
\phi=\int_{p}^{P_{r}} \alpha d p-\left.\left(P_{r}-\bar{P}\right) \alpha\right|_{P_{r}}
$$

Note that for $P_{r}=\bar{P}$, equation (A3) defines the classic geopotential height anomaly. For the region under consideration, neglecting the second terms in (A2) leads to velocity errors of less than $1 \mathrm{~cm} \mathrm{~s}^{-1}$. Mathematical manipulation of (A2) yields the eastward and northward transport components per unit length, $Q_{u}$ and $Q_{v}$, through integration between fixed constant pressure levels $P_{1}$ and $P_{2}$ :

$$
\begin{gathered}
Q_{v}=-\frac{\partial}{\partial x}(\psi / f)+C_{v} \\
Q_{u}=\frac{\partial}{\partial y}(\psi / f)+\frac{\psi}{f^{2}} \frac{d f}{d y}+C_{u}
\end{gathered}
$$

where the definitions

$$
\begin{gathered}
\psi=\int_{P_{1}}^{P_{2}} \phi d p \\
C_{u}=\left.\left(P_{r}-\bar{P}\right)\left(P_{2}-P_{1}\right) \frac{\partial \delta}{\partial y}\right|_{P_{r}} \\
C_{v}=\left.\left(P_{r}-\bar{P}\right)\left(P_{2}-P_{1}\right) \frac{\partial \delta}{\partial x}\right|_{P_{,}}
\end{gathered}
$$

for the variable pressure reference corrections have been used. Simply approximating the transport stream function as $\psi / f$ would lead to systematic nonzero transports, even for vanishing eastward velocity component, because of the meridional variation of the Coriolis parameter. Since we do not wish to fully integrate (A4) to determine the transport stream function, we introduce the function

$$
\psi^{*}=\psi(x, y)+\bar{\psi}(y)
$$

and rewrite $\mathrm{A} 4$ to find

$$
Q_{v}=\frac{\partial}{\partial x}\left(\psi^{*} / f\right)+C_{v}
$$

$$
Q_{u}=\frac{\partial}{\partial y}\left(\psi^{*} / f\right)-(1 / f) \frac{d \bar{\psi}}{d y}+\left(1 / f^{2}\right) \frac{d f}{d y}(\bar{\psi}+\psi)+C_{u} .
$$

We now define $\bar{\psi}(y)$, the condition that the zonal integral over the second and third terms in $Q_{u}$ shall vanish, i.e.,

$$
\frac{d \bar{\psi}}{d y}-\frac{1}{f} \frac{d f}{d y} \bar{\psi}=\frac{1}{\left(x_{2}-x_{1}\right)} \frac{1}{f} \frac{d f}{d y} \int_{x_{1}}^{x_{2}} \psi d x .
$$

Solving (A7) in $3^{\circ}$ latitude stripes for $\bar{\psi}$ and applying $\bar{\psi}(y)$ to (A6) results in $\psi^{*} / f$, a good approximation of the transport stream function. The errors due to variable $f$ are zero when zonally integrated, and those due to a variable pressure reference are relatively small in transport (less than $1 \mathrm{~cm} \mathrm{~s}^{-1}$ in velocity) in the region under consideration.

Acknowledgments. We thank N. Panteleyev and J. Chekalin for providing additional CTD data, and B. Klein for the silicate data. We also wish to acknowledge G. Siedler and E. Ojaveer, who rendered possible the mutual visits in Kiel and Tallinn. For the help in preparing the manuscript and figures we thank C. Brückner, S. Drews, and C. Tietze. Special thanks go to K. Schultz-Tokos, who carefully read the English manuscript. Appreciation is extended to all scientists and technicians for their assistance in the success of the survey. We are also indebted to the captains and crews of the research vessels Arnold Veimer, Akademik Vernadsky, and Meteor for their help at sea. A substantial part of this study was supported by the Deutsche Forschungsgemeinschaft, Bonn, under grant SFB 133.

\section{REFERENCES}

Armi, L., and W. Zenk, Large lenses of highly saline Mediterranean water, J. Phys. Oceanogr., 14, 1560-1576, 1984.

Armi, L., D. Hebert, N. Oakey, J. F. Price, P. L. Richardson, T, Rossby, and B. Ruddick, Two years in the life of a Mediterranean salt lens, J. Phys. Oceanogr., 19, 354-370, 1989.

Barton, E. D., Meanders, eddies and intrusions in the thermocline front off northwest Africa, Oceanol. Acta, 10, 267-282, 1987.

Bauer, E., and G. Siedler, The relative contribution of advection and isopycnal and diapycnal mixing below the subtropical salinity maximum, Deep Sea Res., 35, 811-837, 1988.

Belkin, I. M., and A. G. Kostianoy, Lenses of Mediterranean Water in the North Atlantic, in Hydrophysical Investigations in the 
"Mesopolygon" Experiment (in Russian), edited by V. G. Kort, pp. 110-123, Nauka, Moscow, 1988.

Belkin, I. M., M. V. Emeljanov, A. G. Kostianoy, and K. N. Fedorov, Thermohaline structure of intermediate waters of the ocean and intrathermocline eddies, in Intrathermocline Eddies in the Ocean (in Russian), edited by K. N. Fedorov, pp. 8-34, P. P. Shirshov Institute of Oceanology, Moscow, 1986.

Bubnov, V. A., and S. Ye. Navrotskaya, Variability of dynamic topography and surface geostrophic currents in the central tropical Atlantic, Oceanology, Engl. Transl., 25, 304-309, 1985.

Byshev, V. I., Yu. A. Ivanov, and V. G. Kort, Evaluation of synoptic disturbances deduced from measurements in northcentral Atlantic, Oceanology, Engl. Transl., 22, 11-14, 1982.

Dickson, R. R., Global summaries and intercomparisons: Flow statistics from long-term current meter moorings, in Eddies in Marine Science, edited by A. R. Robinson, pp. 278-353, SpringerVerlag, New York, 1983.

Dietrich, G., and H. Ulrich, Atlas zur Ozeanographie, 76 pp., Bibl. Inst. Mannheim, Mannheim, Germany, 1968.

Efimov, V. V., and P. E. Boguslavski, The formation of subsurface salinity maximum in the tropical Atlantic (in Russian), Oceanology, 29, 904-908, 1989. (English translation, On the formation of a subsurface salinity maximum in the tropical Atlantic, Oceanology, Engl. Transl., 29, 673-676, 1989.)

Emery, W. J., and J. Meincke, Global water masses: Summary and review, Oceanol. Acta, 9, 383-391, 1986.

Fedorov, K. N., The Thermohaline Finestructure of the Water of the Occan (in Russian), 184 pp., Gidrometeoizdat, St. Petersburg, Russia, 1976. (English translation $\mathbf{7 0}$ pp., Pergamon, New York, 1978.)

Fiadeiro, M. E., and G. Veronis, On the determination of absolute velocities in the ocean, J. Mar. Res., 40, suppl., 159-192, 1982.

Gould, W. J., Physical oceanography of the Azores Front, Prog. Oceanogr., 14, 167-190, 1985.

Hagen, E., Intermediäre Frontzonen vor Kap Verde $\left(15^{\circ} \mathrm{N}\right)$, Beitr. Meereskd., 60, 69-71, 1989.

Hagen, E., and R. Schemainda, Mittlere und jahreszeitliche Strukturen im Unterstrom (UUC) des Auftriebsgebietes vor Nordwestafrika, Beitr. Meereskd., 59, 19-45, 1989.

Joyce, T. M., On in-situ "calibration" of shipboard ADCPs, $J$. Atmos. Oceanic Technol. 6, 169-172, 1989.

Käse, R. H., and G. Siedler, Meandering of the subtropical front southeast of the Azores, Nature, 300(5889), 245-246, 1982.

Käse, R. H., and W. Zenk, Reconstructed Mediterranean salt lens trajectories, J. Phys. Oceanogr., 17, 158-163, 1987.

Käse, R. H., W. Zenk, T. B. Sanford, and W. Hiller, Currents, fronts and eddy fluxes in the Canary Basin, Prog. Oceanogr., 14, 231-257, 1985

Käse, R. H., J. F. Price, P. L. Richardson, and W. Zenk, A quasi-synoptic survey of the circulation and water mass distribution within the Canary Basin, J. Geophys. Res., 91, 9739-9748, 1986.

Klein, B., and G. Siedler, On the origin of the Azores Current, $J$. Geophys. Res., 94, 6159-6168, 1989.

Krauss, W., and C. Wübber, Response of the North Atlantic to annual wind variations along the eastern coast, Deep Sea Res., Part A, 29(7), 851-868, 1982.

Kuksa, V.. The Intermediate Waters of the World Ocean (in Russian), 272 pp., Gidrometeoizdat, St. Petersburg, Russia, 1983.

Luyten, J. R., J. Pedlosky, and H. Stommel, The ventilated thermocline, J. Phys. Oceanogr., 13, 292-309, 1983.

Maillard, C.. Mean circulation and exchanges in the northeastern Atlantic from historical data, Rapp. Pr. V. Reun. Cons. Int. Explor. Mer, 185, 131-139, 1984.

Maillard, C., Atlas hydrologique de l'Atlantique Nord-Est, 32 pp. 133 plates, IFREMER, Brest, 1986.

Maillard, C., and R. Käse, The near-surface flow in the subtropical gyre south of the Azores, J. Geophys. Res., 94, 16,133-16.140, 1989.

McDowell, S., P. B. Rhines, and T. Keffer, North Atlantic potential vorticity and its relation to the general circulation, J. Phys. Oceanogr., 12, 1417-1436, 1982.

McWilliams, J. C., Submesoscale, coherent vortices in the ocean, Rev. Geophys., 23, 165-182, 1985.
Müller, T. J., and G. Siedler, Multi-year current time series in the North Atlantic Ocean, J. Mar. Res., 50, 1-37, 1992.

Olbers, D. J., M. Wenzel, and J. Willebrand. The inference of North Atlantic circulation patterns from climatological hydrographic data, Rev. Geophys., 23, 313-356, 1985.

Onken, R., and B. Klein, A model of baroclinic instability and waves between the ventilated gyre and the shadow zone of the North Atlantic Ocean, J. Phys. Oceanogr., 21, 53-67, 1991.

Pollard, R. T., and S. Pu, Structure and circulation of the upper Atlantic Ocean northeast of the Azores, Prog. Oceanogr., 14, $443-462,1985$.

Pollard, R., and J. Read, A method for calibrating shipmounted acoustic Doppler profilers, and the limitations of gyro compasses, J. Atmos. Oceanic Technol., 6, 859-865, 1989.

Robinson, M., R. Bauer, and E. Schröder, Atlıs of North AtlanticIndian Ocean monthly mean temperatures ind mean salinities of the surface layer, NOORP-I8, $19 \mathrm{pp} ., 54$ platcs, Dep. of the Navy, Washington, D. C., 1979.

Schmitz, W. J., Jr., J. F. Price, and P. L. Richardson, Recent moored current meter and SOFAR float observations in the eastern Atlantic near $32^{\circ} \mathrm{N}, J$. Mar. Res., 4\%, 301-319, 1988.

Siedler, G., W. Zenk, and W. J. Emery, Sirong current events related to a subtropical front in the northe ast Atlantic, J. Phys. Oceanogr., 15, 885-897, 1985.

Siedler, G., A. Kuhl, and W. Zenk, The Madeira Mode Water, J. Phys. Oceanogr., 17, 1561-1570, 1987

Smith, O. P., and J. M. Morrison, Shipboard acoustic Doppler current profiling in the eastern Caribbean Sea, 1985-1986, J. Geophys. Res., 94, 9713-9719, 1989.

Spall, M. A., Circulation in the Canary Basin: A model/data analysis, J. Geophys. Res., 95, 9611-9628, 1990.

Stammer, D., and J. D. Woods, Isopycnic potential vorticity atlas of the North Atlantic Ocean-Monthly mein maps, Ber. 165, 108 pp., Inst. für Meereskd., Univ. Kiel, Kiel. Germany, 1987.

Stramma, L., Geostrophic transport in the warm water sphere of the eastern subtropical North Atlantic, J. Mar. Res., 42, 537-558, 1984.

Stramma, L., and G. Siedler, Seasonal changes in the North Atlantic subtropical gyre, J. Geophys. Res., 93, 8111-8118, 1988.

Sy, A., Investigation of large-scale circulation patterns in the central North Atlantic: The North Atlantic Current, the Azores Current, and the Mediterranean Water plume in the area of the MidAtlantic Ridge, Deep Sea Res., 35, 383-413, 1988.

Wüst, G., Die Stratosphäre des Atlantischen Ozeans, Wiss. Ergeb. Dsch. All. Exped. Vermess. und Forschungsschiff Meteor 1925$1927,6(1), 109-288,1936$.

Yemel'yanov, M. V., and K. N. Fedorov, Structure and transformation of intermediate waters of the Mediterranean Sea and Atlantic Ocean, Oceanology, Engl. Transl., 25, 155-161, 1985.

Zenk, W., and L. Armi. The complex spreading pattern of Mediterranean Water off the Portuguese continental shelf, Deep Sea Res., $37,1805-1823,1990$.

Zenk, W., and T. J. Müller, Seven-year current meter record in the eastern North Atlantic, Deep Sea Res., 35, 1259-1268, 1988.

Zenk, W., T. J. Müller, and G. Wefer (Eds.), BarlaventoExpedition, Reise Nr. 9, Meteor-Ber. 89-2, 238 pp., Inst. für Meereskd. Hamburg, Germany, 1989.

Zenk, W., B. Klein, and M. Schröder, Cape Verde Frontal Zone, Deep Sea Res., 38, suppl. 1, S505-S530. 1991.

A. Aitsam, Institute of Thermophysics and Electrophysics, Academy of Sciences of Estonia, Paldiski Street 1, Tallinn 200001 , Estonia.

J. Elken, Institute of Ecology and Marine Research, Academy of Sciences of Estonia, Paldiski Street 1, Tallinn 200001, Estonia.

V. Fiekas, Forschungsanstalt für Wasserschall- und Geophysik der Bundeswehr, Klausdorfer Weg 2, D-2300 Kiel, Germany.

T. J. Müller and W. Zenk, Institut für Meereskunde an der Universität Kiel, Düsternbrooker Weg 20, D-2300 Kiel 1, Germany.

(Received May 13, 1991;

revised April 27, 1992;

accepted September 29, 1991.) 